\title{
DP-1316 \\ 186740
}

\section{CONFINEMENT OF AIRBORNE RADIOACTIVITY}

\author{
PROGRESS REPORT: JANUARY - JUNE 1972
}
A. G. EVANS
L. R. JONES

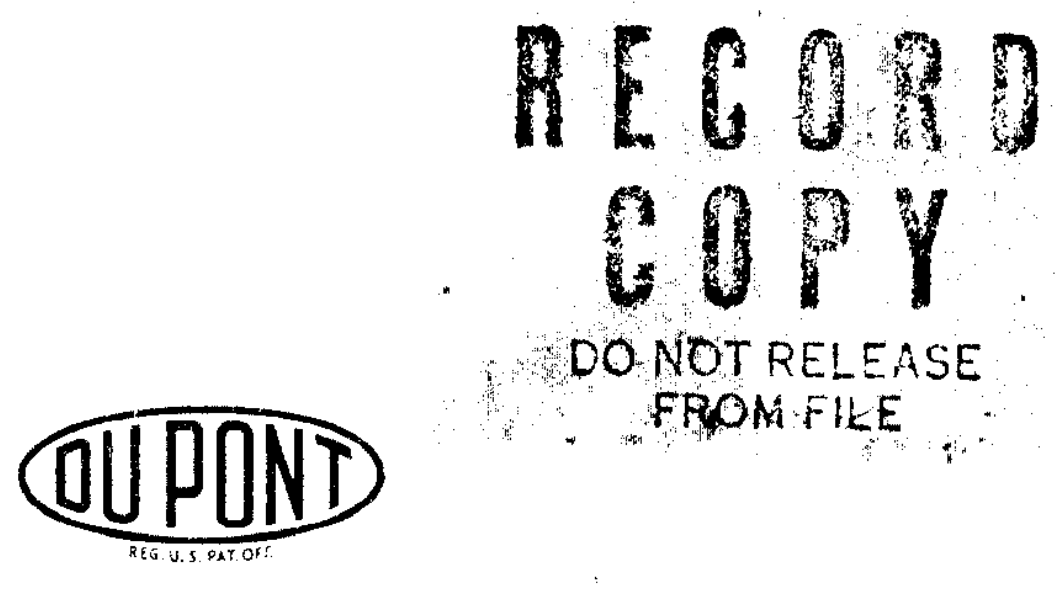

Savannah River Laboratory

Aiken, South Carolina 


\section{NOTICE}

This report was prepared as an account of work sponsored by the United States Government. Neither the United States nor the United States Atomic Energy Commission, nor any of their employees, nor any of their contractors, subcontractors, or their employees, makes any warranty, express or implied, or assumes any legal liability or responsibility for the accuracy, completeness or usefulness of any information, apparatus, product or process disclosed, or represents that its use would not infringe privately owned rights.

Printed in the United States of America Available from

National Technical Information Service

U. S. Department of Commerce

5285 Port Royal Road

Springfield, Virginia 22151

Price: Printed Copy $\$ 3.00$; Microfiche $\$ 0.95$ 


\section{CONFINEMENT OF AIRBORNE RADIOACTIVITY}

PROGRESS REPORT: JANUARY - JUNE 1972

by
A. G. Evans
L. R. Jones

Approved by

J. M. Boswe11, Research Manager

Reactor Engineering Division

January 1973

E. 1. DU PONT DE NEMOURS \& COMPANY

SAVANNAH RIVER LABORATORY

AIKEN, S. C. 29801

CONTRACT AT(07-2)-1 WITH THE

UNITED STATES ATOMIC ENERGY COMMISSION 


\section{ABSTRACT}

A new $1.6 \mathrm{MCi}{ }^{60} \mathrm{Co}$ gamma-irradiation facility and associated carbon testing facility were constructed, and testing was begun on candidate replacement carbons for the confinement system. Radiation testing of other confinement system components was also initiated. Carbons are tested for iodine penetration at an absorbed dose rate of $3.0 \times 10^{7} \mathrm{rad} / \mathrm{hour}$, and other system components at dose rates ranging from $3 \times 10^{6} \mathrm{rad} /$ hour to $4.5 \times 10^{7} \mathrm{rad} / \mathrm{hour}$.

Initial test results indicate that radiolytic desorption of iodine from carbon increases with increased relative humidity, carbon granule size, and loading times. Desorption is relatively unaffected by dust loading on the moisture separator or particulate filter upstream of the test bed.

Both radiation exposure and normal service were found to decrease water repellancy and tensile strength of the particulate filter media. Radiation also causes degradation of fluorocarbon fibers in the moisture separator media and of sponge gasketing material used to seal particulate filters and carbon beds. 


\section{CONTENTS}

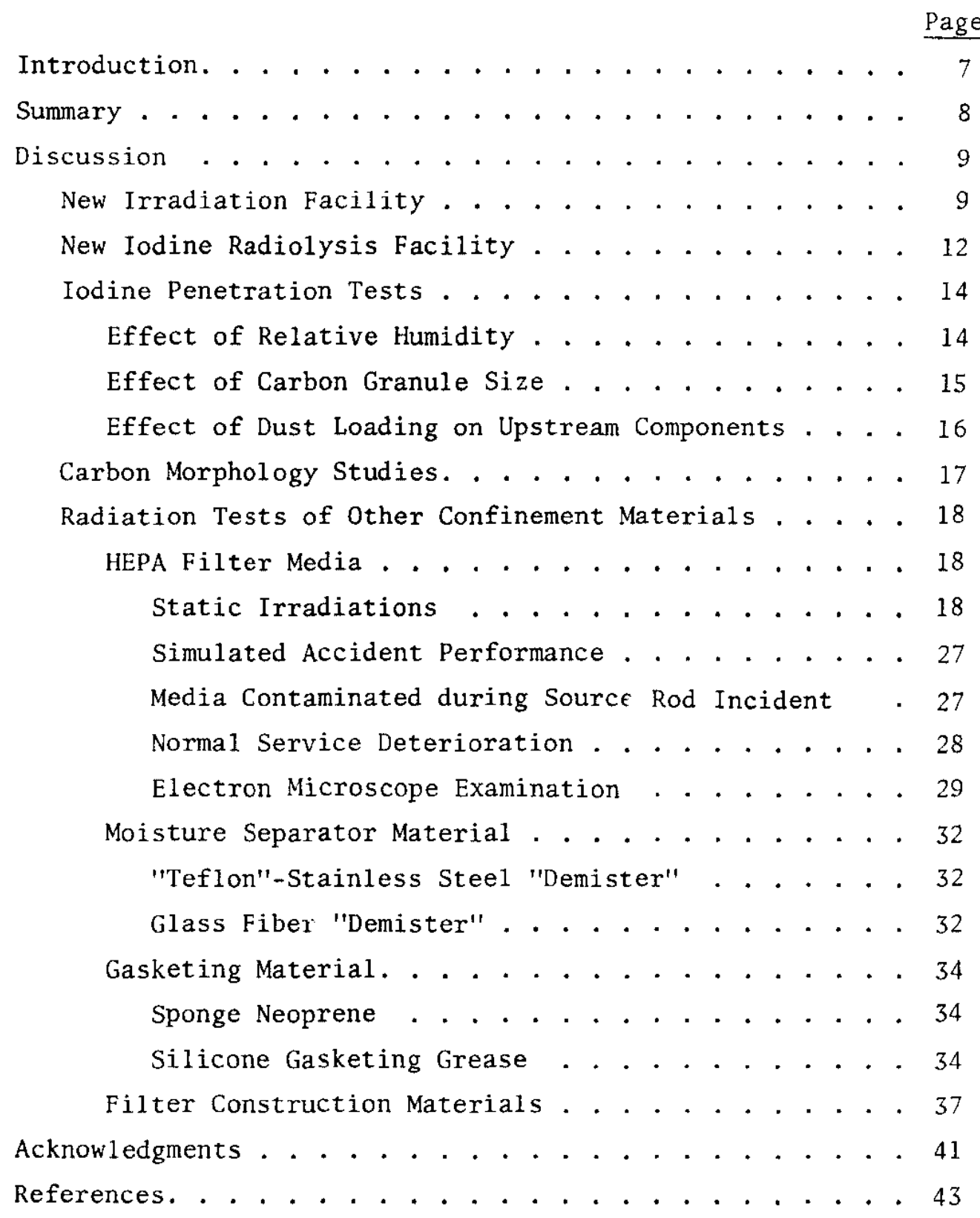




\section{LIST OF TABLES}

Table

Page

I Effect of Relative Humidity on Iodine Penetration of Unimpregnated Carbon . . . . . . . . . . . . . 14

II Effect of Particle Size Distribution on Methyl Iodide Penetration of $0.5 \% \mathrm{KI}$-Impregnated Carbon . . . 15

III Comparison of Radiolytic Desorption between Two Lots of 5\% TEDA-Impregnated Carbon . . . . . . . . . . 15

IV Effect of Particle Size Distribution on Radiolytic Desorption of Iodine from 5\% TEDA-Impregnated Carbon . 16

$V$ Effect of Dust Loaded Upstream Components on Iodine Retention in a Radiation Environment . . . . . . . . 17

VI HEPA Filter Irradiation Summary . . . . . . . . . . 26

VII Filter Units Contaminated in Antimony Source Rud Incident . . . . . . . . . . . . . . . . . 27

VIII Water Repellancy of Media with Service in Confinement System . . . . . . . . . . . . . . . . . . . . . 29

IX Separator Irradiation Summary . . . . . . . . . 38

$\mathrm{X}$ Adhesive Irradiation Summary . . . . . . . . . . 39 


\section{LIST OF FIGURES}

$\underline{\text { Figure }} \underline{\text { Page }}$

1 Slug Holder Positioned Around Access Tube . . . . . . 9

2 Slug Holder Positioned Around Irradiation Can . . . 10

3 Irradiation Can with Gasket Coupons . . . . . . . . . II

4 Iodine Radiolysis Facility. . . . . . . . . . . . . 12

5 Exploded View of New Test Apparatus . . . . . . . . . 13

6 Assembled View of New Test Apparatus . . . . . . . 13

7 Coal-Base Carbon, 20x . . . . . . . . . . . 18

8 Coal-Base Carbon, 1000X ............. 18

9 Petroleum-Base Carbon, 20X . . . . . . . . . 19

10 Petrol eum-Base Carbon, 1000X . . . . . . . . . 19

11 Coconut-Base Carbon $\left(1000 \mathrm{~m}^{2} / \mathrm{g}\right), 20 \mathrm{x}$. . . . . . 20

12 Unimpregnated Coconut-Base Carbon $\left(1000 \mathrm{~m}^{2} / \mathrm{g}\right), 1000 \mathrm{X} 20$

13 Coconut-Base Carbon $\left(1700 \mathrm{~m}^{2} / \mathrm{g}\right), 20 \mathrm{x}$. . . . . . . 21

14 Coconut-Base Carbon $\left(1700 \mathrm{~m}^{2} / \mathrm{g}\right), 1000 \mathrm{x}$. . . . . . 21

15 Hole in Coconut Carbon $\left(1000 \mathrm{~m}^{2} / \mathrm{g}\right), 50 \mathrm{x}$. . . . . . 22

16 Coconut Carbon Rib Structure in Hole, 1000X . . . . . 22

17 Detail of Coconut Rib Structure, 5000X . . . . . . 23

18 Porosity of Coconut Carbon Rib Structure

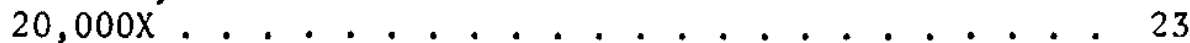

19 HEPA Filter Media $\mathrm{H}_{2} \mathrm{O}$ Repellancy vs Exposed Gamma Dose . . . . . . . . . . . . . . 25

20 HEPA Filter Wet Strength vs Exposed Gamma Dose . . . 26

21 Exposure of SRP HEPA Filter Media to Saturated Air Flow . . . . . . . . . . . 29

22 Scanning Electron Microscope Examination of Irradiated HEPA Filter Media . . . . . . . . 30

23 Scanning Electron Microscope Examination of Used HEPA Filter Media . . . . . . . . . . . 31

24 "Teflon" and Stainless Stee1 "Demister" Material . . . 33

25 Glass Fiber "Demister" Material . . . . . . . . 33 
26 Neoprene Sponge Gasket Samples . . . . . . . . . . 35

27 Shore Hardness of Sponge Neoprene Gasket vs Exposed Gamma Dose . . . . . . . . . . . . . . . . 35

28 Silicone Grease Samples . . . . . . . . . . . . 36

29 Shore Hardness of Silicone Gasketing Grease vs Exposed Gamma Dose . . . . . . . . . . . . . 36

30 Separator Material . . . . . . . . . . . . 38

31 Adhesive Samples . . . . . . . . . . . . . . . 39

32 Framing Materials .. . . . . . . . . . . 40 


\section{INTRODUCTION}

The activity confinement system for each Savannah River production reactor is designed to collect halogens and particulates that might be released in the unlikely event of a reactor accident. ${ }^{1}$ A continuing program is in progress at the Savannah River Laboratory to evaluate the performance of the confinement system for removing airborne radioactivity under adverse operating conditions and to develop techniques to enhance its reliability and efficiency.

Previous confinement system studies at Savannah River have shown that elemental iodine retention on activated carbon is most strongly influenced by the operating temperature of the carbon beds, the moisture content of the air passing through the beds, the length of time the carbon has been in service, and the radiation exposure to which the beds are subjected after iodine loading. ${ }^{2} 10$ Radiation exposure in the carbon beds would result from adsorption and subsequent decay of radioiodine following a reactor accident. Radiolytic desorption of iodine is primarily a free radical reaction in which organic iodides are formed and desorbed from the carbon. ${ }^{9}$ The controlling parameters are radiation intensity, radiation duration, carbon type, carbon service history, and the composition and relative humidity of the purge gas stream. ${ }^{9,10}$ Radiation desorption measurements in a new test apparatus in a newly constructed 1.6-MCi ${ }^{60} \mathrm{Co}$ irradiation facility confirm earlier observations on ratecontrolling parameters. The measurements also indicate some dependence on the particle size distribution of the carbon granules.

Radiation effects on other confinement system components were also studied in the new irradiation facility. Qualitative effects and semiquantitative data are presented for high-efficiency particulate air (HEPA) filter media, moisture separator ("Demister"*) media, and gasketing and adhesive materials.

* Registered tradename of Otto York Co. 


\section{SUMMARY}

Elemental iodine, carbon, and moisture combine in an intense gamma radiation field to form organic iodides. The rate of formation and subsequent desorption is a function of radiation field strength, carbon type, service history, particle size, and the moisture content of the purge gas stream. Unimpregnated carbons desorb the organic iodides more readily than impregnated carbons. Among new impregnated carbons, the coconut-shell carbons impregnated with TEDA or with TEDA and KI have the best overall retention characteristics. Weathered impregnated carbons will be tested in a radiation environment as samples become available.

Asbestos HEPA filter separator materials irradiated in a ${ }^{60} \mathrm{Co}$ gamma field were not significantly affected by the radiation exposure. Two-rubber-base HEPA filter adhesives showed adequate bond strength after irradiation, while one foam adhesive showed complete loss of bonding ability. HEPA filter framing materials retained their integrity at exposures less than $10^{8}$ rads but became brittle at greater exposures. Neoprene sponge gasketing materials were hardened and embrittled at exposures greater than $4 \times 10^{8}$ rads. Silicone greases proposed as substitutes for the sponge neoprene material were hardened and formed voids at exposures less than $1 \times 10^{8}$ rads and crystallized at greater exposures. "Teflon" fibers used in moisture separators disintegrated at exposures greater than $2 \times 10^{7}$ rads, while glass fiber "Demister" material was not damaged. Glass fiber HEPA filter media showed degradation of water repellency and wet strength following irradiation. Some types of media were severely degraded at exposures of $\sim 3 \times 10^{7}$ rads; others required exposures greater than $2 \times 10^{8}$ rads for similar degradation. The deterioration of HEPA filters with normal service in Savannah River confinement facilities is being investigated.

\footnotetext{
* Registered Trademark of E. I. du Pont de Nemours \& Co.
} 


\section{DISCUSSION}

\section{NEW IRRAOIATION FACILITY}

A new $1.6 m \mathrm{MC}{ }^{60} \mathrm{Co}$ irradiation facility and an jodine radiolysis facility were constructed, and intial test results were obtained in the new facilities. The irradiation facility contains a ring of 28 slugs (each containing approximately $58,000 \mathrm{C}$. ${ }^{56} \mathrm{Co}$ ) in a 12.5minch-dianeter circular array, housed in a 24 wt-deep by 8 ft-diameter water-filled pit. The slugs used in the array are segments of control rods irradiated during a recent production program. Materials being insadiated in the new facility can be lowered into the radiation field through a 10 mehmiameter, air filled access tube or through water in immersible containers. The slug holder is of a hinged, clamshell design, which permits positioning arownd the access tube (Figure 1) or on a hollow stomage rack a short distance away from the access tube (Rigure 2).

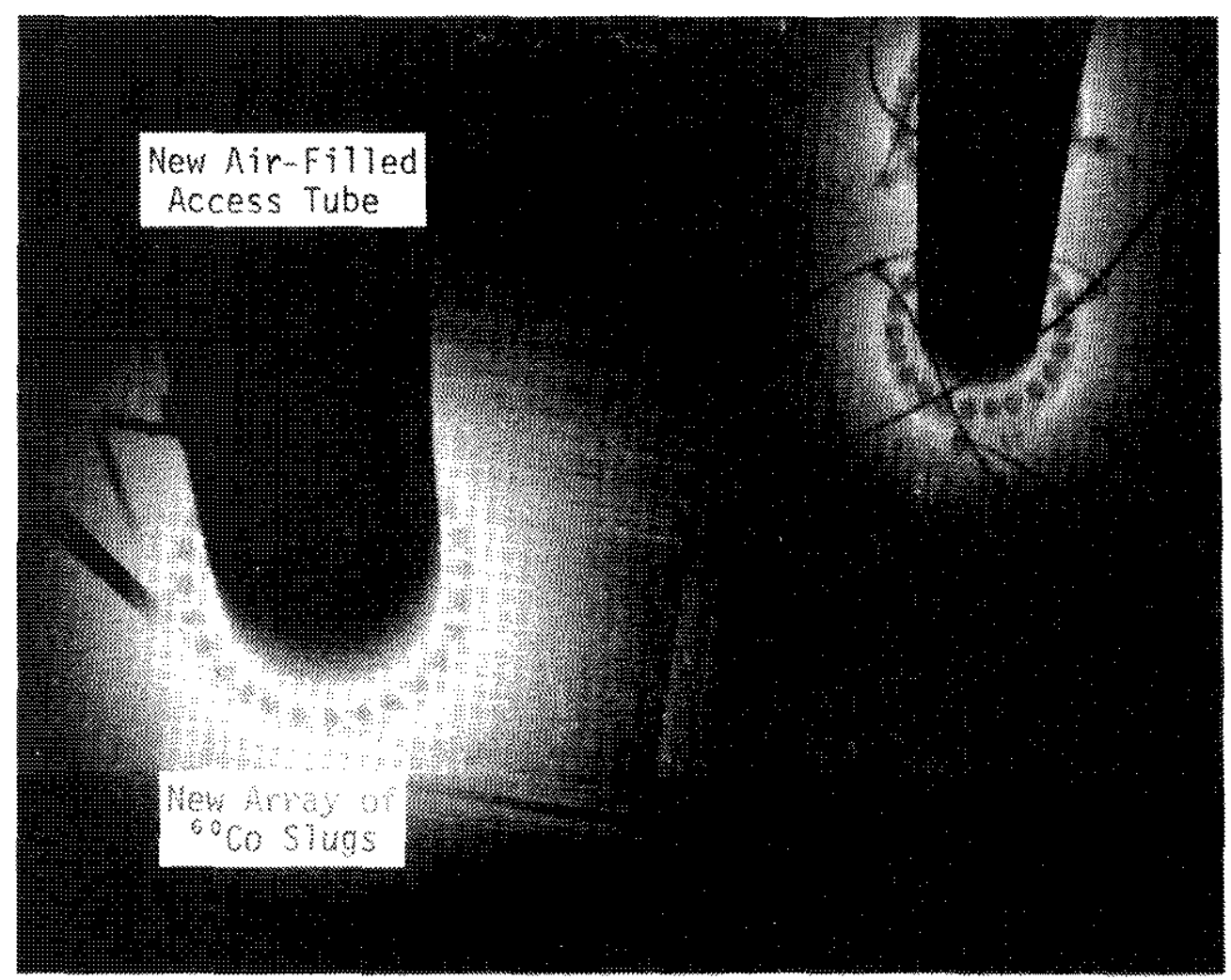

FIGURE 1. Slug Holder Posttioned Around Access Tube 


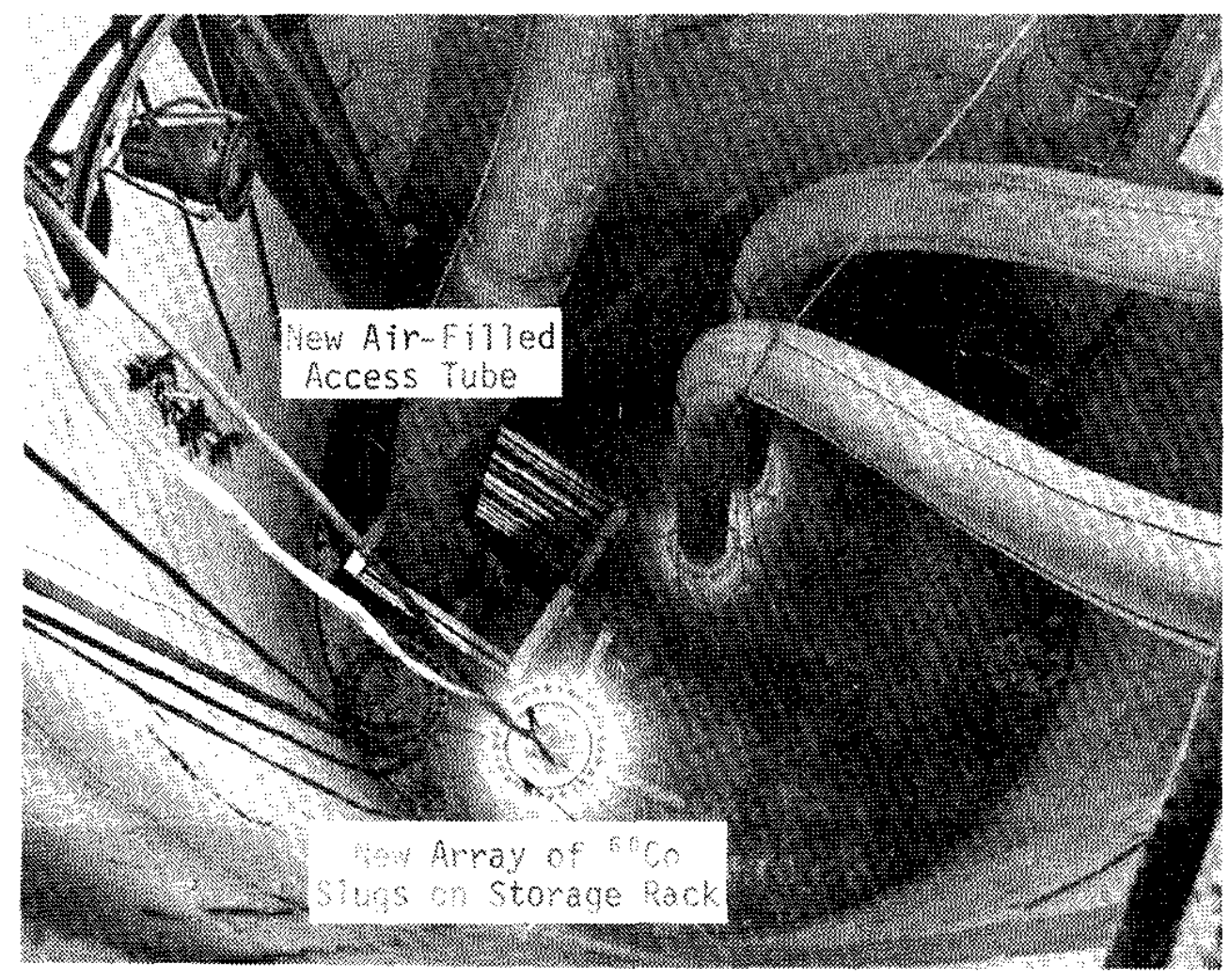

FIGURE 2. SIug Holder Positioned Around Irradiation Can

Dynamic tests of confinement system components requiping continous air flow are pewformed in the access tube. Gama heating of test equipment components necessitates forced-water cooling of the pieces during tests in the access tube. Static tests can be performed on a variety of materials by lowering containers through the pit water into the center of the storage rack. Because the static tests are perfomed in pit water, less elaborate cooling systems are requixed. Wettable samples can be lowered directly into the pit: samples that must be kept dry are irradiated in sealed cans equipped with air purge lines.

Dose rates for dynamic tests range from $3.0 \times 10^{5} \mathrm{rad} / \mathrm{hour}$ at the bottom of the test assembly to $3.0 \times 10^{7} \mathrm{rad} / \mathrm{hr}$ in the carbon test bed at the top of the test assembly. Dose rates for static tests vary with the size and cooling mode used for irradiation. A 5-inchudianeter sealed can (Figure 3 ) used for static ixradiation tests has an average dose rate of approximately $4.5 \times 10^{7} \mathrm{rad} / \mathrm{hr}$ in samples hanging from the support spindle. 


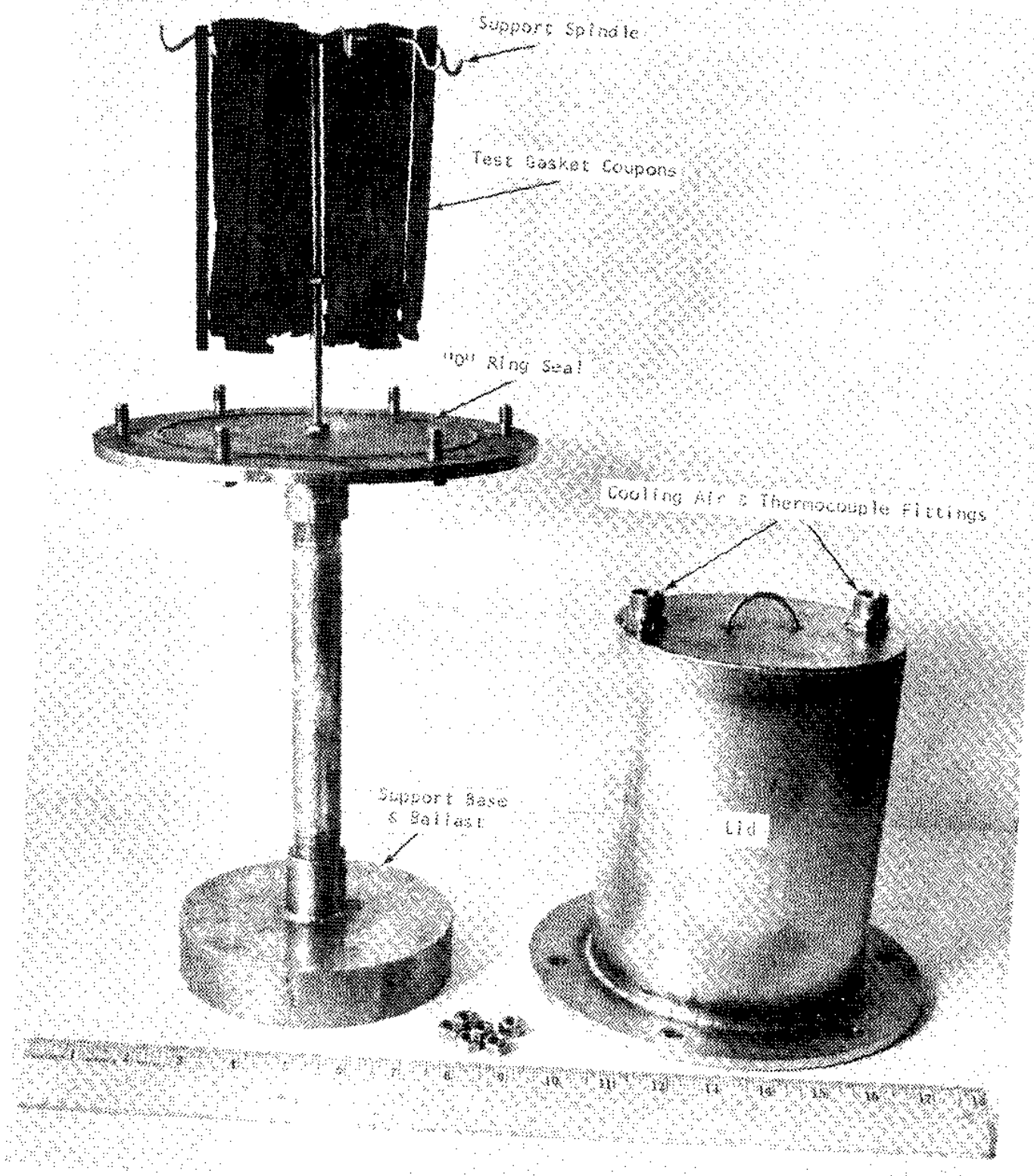

FIGURE 3. Irradiation Can with Gasket Coupons 


\section{HEW IODINE RAOIOLYSIS FACILITY}

For dynamic tests, both the cobalt irradiation facility and iodine radiolysis facility (Figure 4) are used. For these tests, air is first prefiltered through carbon and then drawn into a chamber where air, steam, and iodine are mixed to produce the desired temperature, humidity, and iodine concentrations. The test mixture then passes through a jacketed line to the test apparatus in the irradiation facility. Water is circulated through the outer chamber in the jacketed line to provide heating or cooling as desired for the specific test. Test air entering the irradiation assembly passes sequentially through moisture separator media, IEPA 1 ilter media, and a carbon test bed before exiting to a jacketed return line. lodine penetration of the carbon bed is detemined by passing the test air through a water-cooled condenser to remove excess moisture, and then through a series of -inch-deep backup carbon beds. Heated air can be introduced between the condenser and backup beds to reduce the relative humidity of test air entering the backup beds. The entire test assembly is maintained under negative pressure by a paix of exhaust punps downstream of the backup beds.

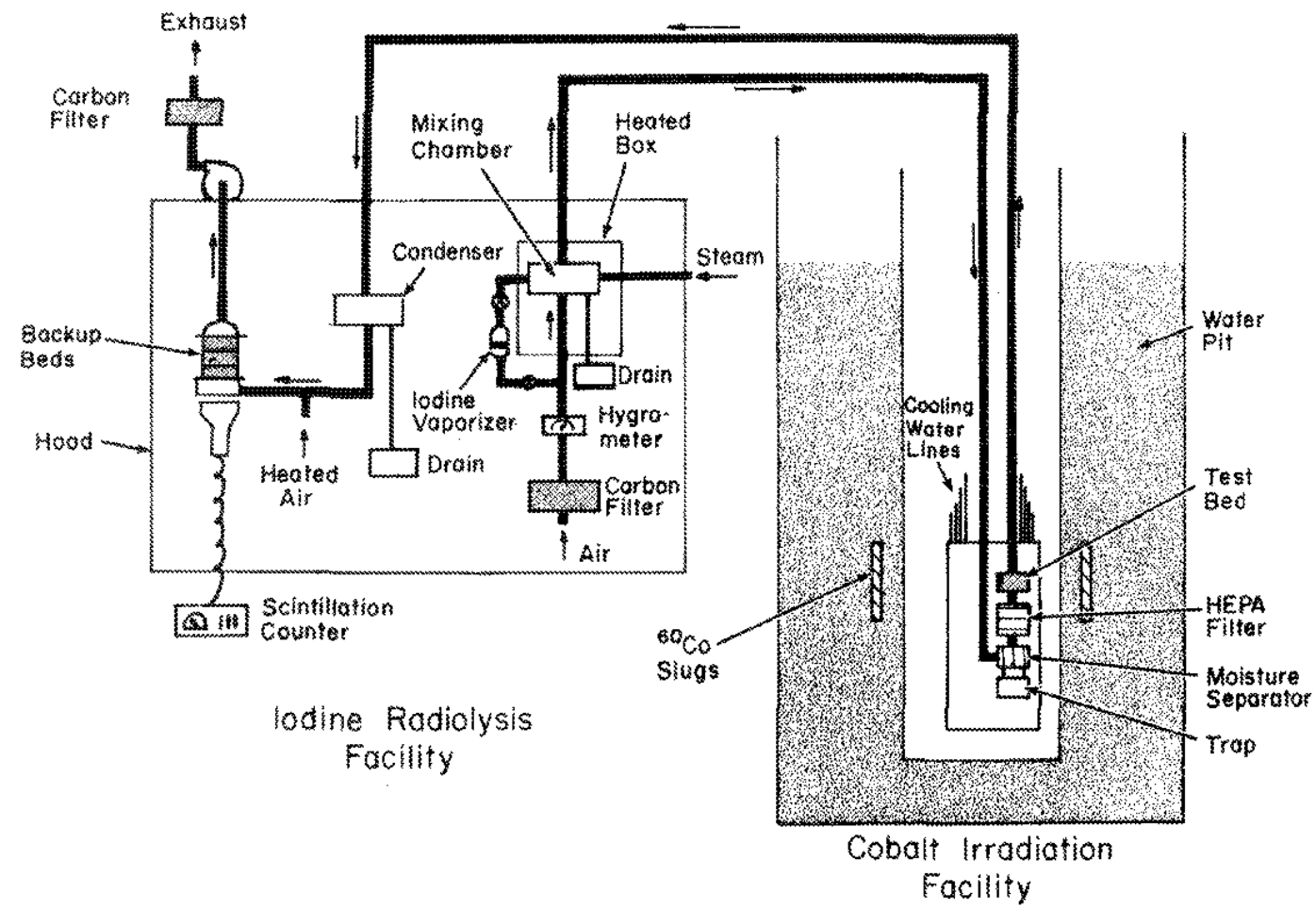

FIGURE 4. lodine Radiolysis Facility 
The test apparatus (Figure 5) is designed to provide equivalent face velocities to those encountered by comparable components in the confinement system. ${ }^{9}$ A condensate trap at the bottom of the assembly minmizes variations in relative humity. These variations were difficult to control in the oldex test apparatus. 9,10 All the test apparatus pieces are hollow and have pressurized cooling water lines to renove gama heat generated in the stainless steel. An assembled view of the test apparatus, with cooling water lines in place, is shown in ligure 6 . The lower $8 \mathrm{ft}$ of sample and cooling water lines connected to the test apparatus are stainless steel (rigid or flexible) because comentional rubber or plastic flexible tubing deteriorates rapidly in the high intensty radiation piold. plastic tubing "Tetlon" sample Iines, polyethylene and polyvinyl chloride water lines) is used above the maximu field areas to minimize iodine plating and reduce weight in the tubing bundle. The 10-inch aluminum access tube is continuous $1 y$ purged with 5 to $10 \mathrm{cfm}$ air to minimize corrosion of the aluminum from buildup of nitric acid fumes foxmed by radiolysis of air. Jacketed lines are fabricmreinforced neoprene which resists deterioration by hot water (up to $115^{\circ} \mathrm{C}$ ) and radiolytically formed ozone and nitric acid funes.

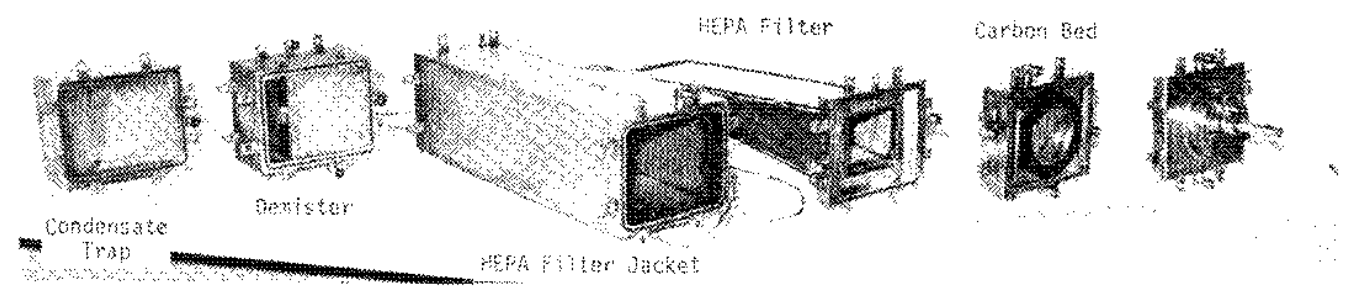

FIGURE 5. Exploded View of New Test Apparatus

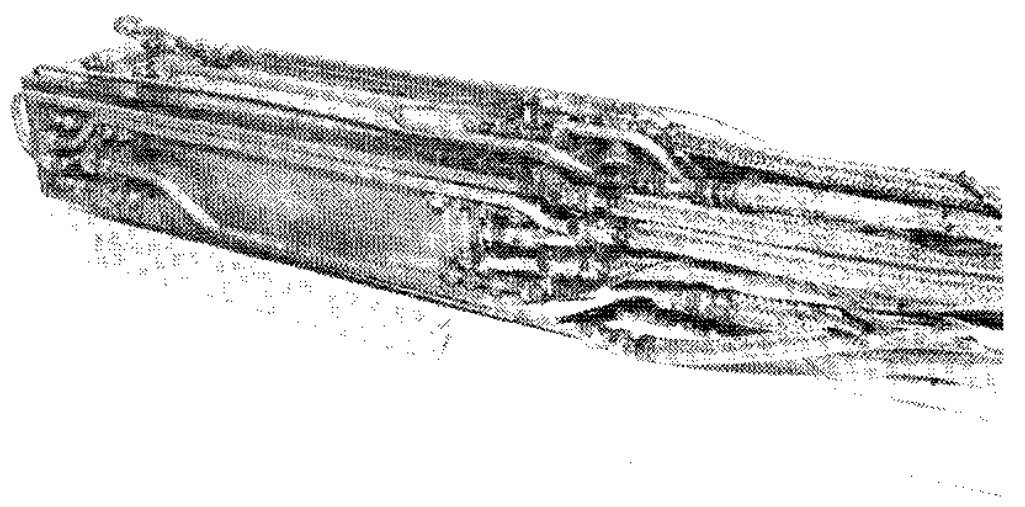

FIGUPE 6. Assembled View of New Test Apparatus 
The initial radiolytic desorption tests in the new facilities were designed to extend the results obtained from the radiation screening tests run in the older test facilities. ${ }^{9,10}$ Data obtained in the new test apparatus indicate the relative humidity of the test air stream (previously reported as $50 \% 9,10$ ) was probably closer to 70 to $80 \%$ as shown in Table 1 .

\section{TABLE I}

Effect of Relative Humidity on Iodine Penetration of Unimpregnated Carbon

$\begin{array}{cc}\begin{array}{c}\text { Relative Humidity, } \\ \%\end{array} & \begin{array}{c}\text { lodine Penetration, } \% \\ \left(5 \text { hours at } 80^{\circ} \mathrm{C}\right)\end{array} \\ \begin{array}{l}50^{a} \\ 25^{b} \\ 100^{a}\end{array} & 0.14 \\ & 0.28 \\ & 0.37 \\ \text { b New test apparatus, } 3.0 \times 10^{7} \mathrm{rad} / \mathrm{hr} \text { absorbed dose rate. } & 1.5 \times 10^{7} \mathrm{rad} / \mathrm{hr} \text { absorbed dose rate. }\end{array}$

In the older apparatus, condensate and entrained moisture could accumulate at the bottom of the incoming air plenum. Test air entering the plenum was directed over the surface of the accumulated liquid. Thus, the relative humidity of the incoming air stream was increased. The newer apparatus is equipped with a moisture separator and condensate trap assembly, which minimizes re-evaporation thus permitting more reproducible humidity control.

Previous measurements of radiolytic desorption of iodine indicated a strong dependence on the radiation dose rate in the carbon bed. 9 Because the absorbed dose rate in the new test apparatus is twice that in the old apparatus $\left(3.0 \times 10^{7}\right.$ $\mathrm{rad} / \mathrm{hr}$ ), radiolytic desorption in the new apparatus was expected to be 2 to 4 times higher. The expected increase did not occur, however, suggesting a possible ionization saturation phenomenon at higher dose rates. Additional tests with varying dose rates and humidities will be required. 
Collins ${ }^{11}$ reported a strong particle size influence on methyl iodide penetration of KI-impregnated carbons (Table II). When nonuniformities in particle size distributions were observed among different lots of vendor-supplied carbon, a series of tests were undertaken to evaluate the effect of particle size on radiolytic desorption of iodine. In initial tests, the penetration varied by a factor of two between different lots of TEDAimpregnated carbon (Table III).

\section{TABLE II}

Effect of Particle Size Distribution on Methyl Iodide Penetration of 0.5

KI-Impregnated Carbon ${ }^{11}$

$\begin{array}{rc}\begin{array}{c}\text { Particle Size } \\ \text { Distribution, U. S. Mesh }\end{array} & \begin{array}{c}\text { Methyl lodide Pen } \\ \text { (Room Temp, } 90 \text { to }\end{array} \\ 8 \text { to } 12 & 0.175 \\ 12 \text { to } 16 & 0.01 \\ 18 \text { to } 30 & <0.001\end{array}$

TABLE II I

Comparison of Radiolytic Desorption between Two Lots of 5\% TEDA-Impregnated Carbon
Particle Size Distribution, U.S. Mesh

lodine Penetration, \% (5 hours at $80^{\circ} \mathrm{C}, 100 \%$ R.H., $3.0 \times 10^{7} \mathrm{rad} / \mathrm{hr}$ )

Lot 1

$64 \% 8$ to 12 mesh

$36 \% 12$ to 16 mesh

0.157

Lot 2

$34 \% 8$ to 12 mesh

$66 \% 12$ to 16 mesh

0.077 
The observed penetrations in these tests were usually high for a TEDA-Impregnated carbon because moisture condensed in the downstream $1 \mathrm{eg}$ of the test apparatus and dripped back into the test bed. However, the ratio of penetration through coarse and fine carbons is valid even if the absolute value of penetration is unrealistic for a well-designed carbon adsorber system.

Equipment operating procedures were modified to prevent condensation near the test bed; results are shown in Table IV.

TABLE IV
$\begin{aligned} & \text { Effect of Particle Size Distribution on Radiolytic } \\ & \text { Desorption of Iodine from 5\% TEDA Impregnated } \\ & \text { Carbon }\end{aligned}$
$\begin{array}{r}\text { Particle Size Distribution, } \\ \text { U.S. Mesh }\end{array}$
$\begin{array}{r}\text { lodine Penetration, } \% \\ \text { and } 3.0 \times 10^{7} \text { rad } / \mathrm{hr}\end{array}$
$\begin{array}{rl}8 \text { to } 10 & 0.041 \\ 12 \text { to } 16 & 0.020\end{array}$

a All particles screened from the same lot of carbon.

\section{Effect of Dust Loading on Upstream Components}

The Savannah River activity confinement system is a multicomponent filtration train that continuously removes airborne contaminants from the reactor building exhaust air before the air is discharged to the environment. Although the system was designed to minimize the release of radioactive materials under accident conditions, it also efficiently removes the normal nonradioactive atmospheric pollutants present in the supply air as well as those produced within the buildings. A portion of the dust that accumulates on the moisture separator and HEPA filters is a sooty material resulting from operation of nearby fossil fueled power and steam generating facilities. The presence of carbon-rich dusts upstream of the iodine adsorber beds could result in significantly increased iodine loadings on the moisture separators and HEPA filters and subsequent increased conversion of inorganic iodides to organic iodides in a radiation environment. A series of tests was run to evaluate the amount of iodine deposited on the upstream components and its effect on retention by the activated carbon. The tests were intentionally run at high humidity with unimpregnated carbon in the test bed to minimize retention of organic iodides formed in the upstream components. Increased iodine pickup on the upstream components was observed, but no significant increase in iodine penetration of the test bed was noted. Test results are summarized in Table $V$. 
TABLE $V$

Effect of Dust-Loaded Upstream Components on Iodine Retention in a Radiation Environment

\begin{tabular}{|c|c|c|c|c|}
\hline \multicolumn{2}{|c|}{ Upstream Media } & \multirow{2}{*}{\multicolumn{2}{|c|}{$\begin{array}{l}\text { lodine Retention, } \\
\% \text { of inventory }\end{array}$}} & \multirow[b]{2}{*}{$\begin{array}{l}\text { lodine Penetratior } \\
\text { of Test Bed, } \% \\
\end{array}$} \\
\hline $\begin{array}{l}\text { Moisture } \\
\text { Separator (MS) }\end{array}$ & $\begin{array}{l}\text { HEPA Filter } \\
(\mathrm{HF})\end{array}$ & & & \\
\hline New & New & 0.32 & 0.44 & 0.37 \\
\hline Used & New & 2.22 & 0.86 & 0.44 \\
\hline New & Used & 0.37 & 1.44 & 0.44 \\
\hline
\end{tabular}

a 5 -hour test at $80^{\circ} \mathrm{C}$ and $100 \%$ R. H. in a radiation field of $3.0 \times 10^{7} \mathrm{rads} / \mathrm{hour}$.

\section{CARBON MORPHOLOGY STUDIES}

Many raw materials have been used in the manufacture of industrial activated carbon (i.e., peanut hulls, pecan hulls, sugar, wood, plastics, bone char, coconut shells, coal, petroleum); however, only the last three base carbons are used to any extent for gaseous iodine removal. As an adjunct to the iodine retention screening tests, 9,10 samples of each of these three types of carbons were examined with a scanning electron microscope to characterize the morphology of the exposed surfaces. The resulting photomicrographs reveal marked differences in macrostructure as would be expected from differences in starting materials and methods of manufacture.

The $\mathrm{PbI}_{2}$-impregnated, coal-base carbon (Figure $7,20 \mathrm{X}$ ) is made from finely pulverized coal, which is reconstituted into granules under pressure with suitable binders. The binder is burned out of the granules in the carbonization step of manufacture, leaving a highly structured material with the appearance of pumace. The highly irregular surface is also apparent at 1000X (Figure 8).

The $\mathrm{KI}_{3}$-impregnated, petroleum-base carbon is apparent1y made by a filter cake process. Extensive fracturing is visible in the individual granules, which resemble dried clay (Figure 9). The softer structure of the petroleum carbon is also apparent in this low magnification view (20X) from the rounded, weatherworn appearance of the individual granules. At 1000X, the fractured structure is still apparent (Figure 10). Small rounded cavities on the exposed surfaces of the petroleum-base carbon indicate gas evolution during some step in the manufacturing process. 
Coconut-she11 carbons are crysta11ine in appearance with sharp fracture surfaces and edges similar to crushed rock (Figure 11, $20 \mathrm{X})$. At higher magnification $(1000 \mathrm{X})$ and medium surface area ( $\left.1000 \mathrm{~m}^{2} / \mathrm{g}\right)$, coconut carbon still has regular flat surfaces, but small pores are evident in the structure (Figure 12).

Coconut-shel1 carbons with a high surface area $\left(\sim 1700 \mathrm{~m}^{2} / \mathrm{g}\right.$ have more rounded corners and less regular surfaces (Figure 13, $20 \mathrm{X}$ ). At higher magnification (Figure 14, 1000X), ridges are visible on the surface where the higher degree of activation has resulted in greater surface erosion.

Additional morphological features of coconut carbons can be seen in Figures 15-18. Occasional holes penetrate grains of carbon as shown in Figure $15(50 \mathrm{X})$. At 1000X, rib-like structures along the vertical axes of the holes can be seen (Figure 16). Detail structure of the ribs is shown at 5000X in Figure 17; additional porosity of the rib structure can be seen at $20,000 \mathrm{X}$ in Figure 18. Small holes can be seen in the individual rib sections.

Sma1l, dust-like particles are visible on the surfaces of all types of carbon examined. Their presence on impregnated and unimpregnated carbons indicates that these are very fine carbon particles, which are probably held to the large carbon granules by electrostatic attraction. Impregnants in the carbon are not visible in any of the photomicrographs.

\section{RADIATION TESTS OF OTHER CONFINEMENT MATERIALS}

\section{HEPA Filter Media}

\section{Static Irradiations}

Samples of glass fiber HEPA filter media used in confinement facilities at Savannah Rive ${ }_{i}$, and five other medias (A-F) produced by different manufacturers or by different processes, were irradiated to various exposures in a gamma field of $24.5 \times 10^{7}$ $\mathrm{rad} / \mathrm{hr}$. Changes in media properties were measured both at Savannah River and at the Naval Research Laboratory in Washington, D.C. Tensile strength tests, DOP penetration, dry air flow resistance, weight per unit area, moisture and combustible content, and thickness measurements ${ }^{12}$ on HEPA filter media were made at the Naval Research Laboratory. Relative measurements of water repellency and wet strength of HEPA filter media were made at Savannah River.

Each sample of media was clamped between two flanges containing 2-inch-diameter holes. Alignment of these holes left a 2-inch-diameter area of the sample media exposed and unsupported 


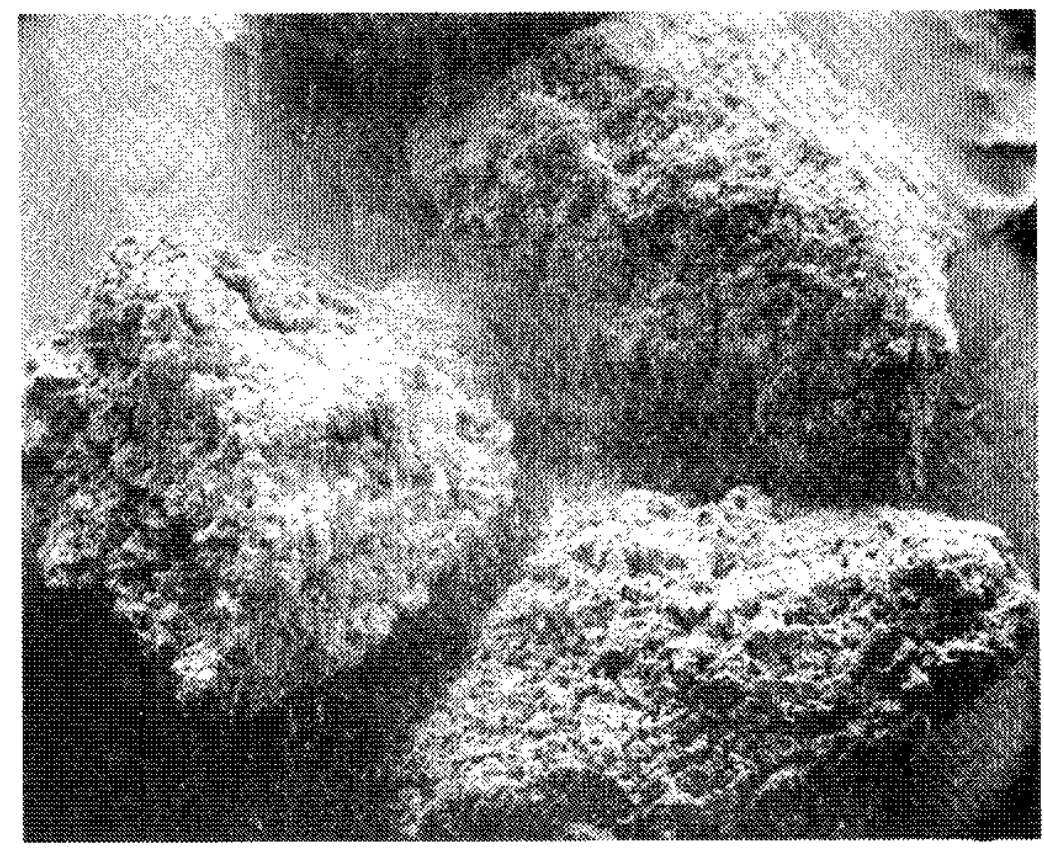

FIGURE 7. Conlmase Cambon, 20x

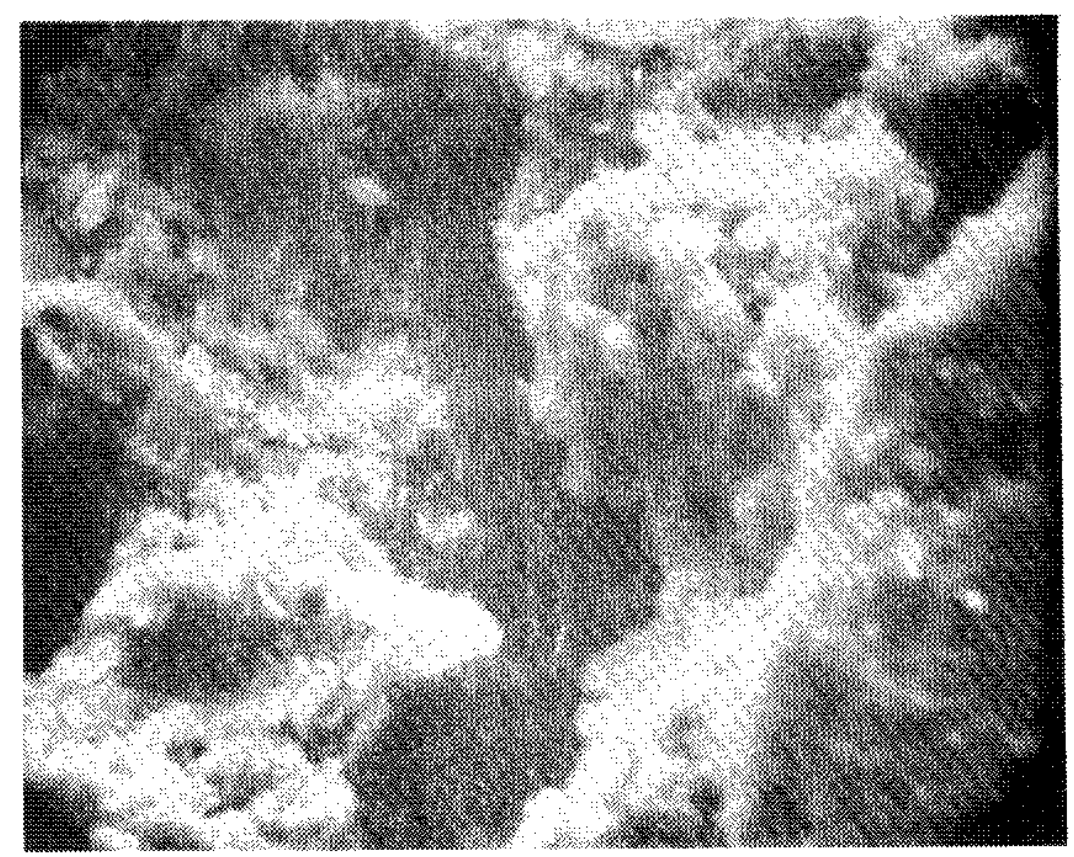

FICURE 8. Coal-base Carbon, 1000X 


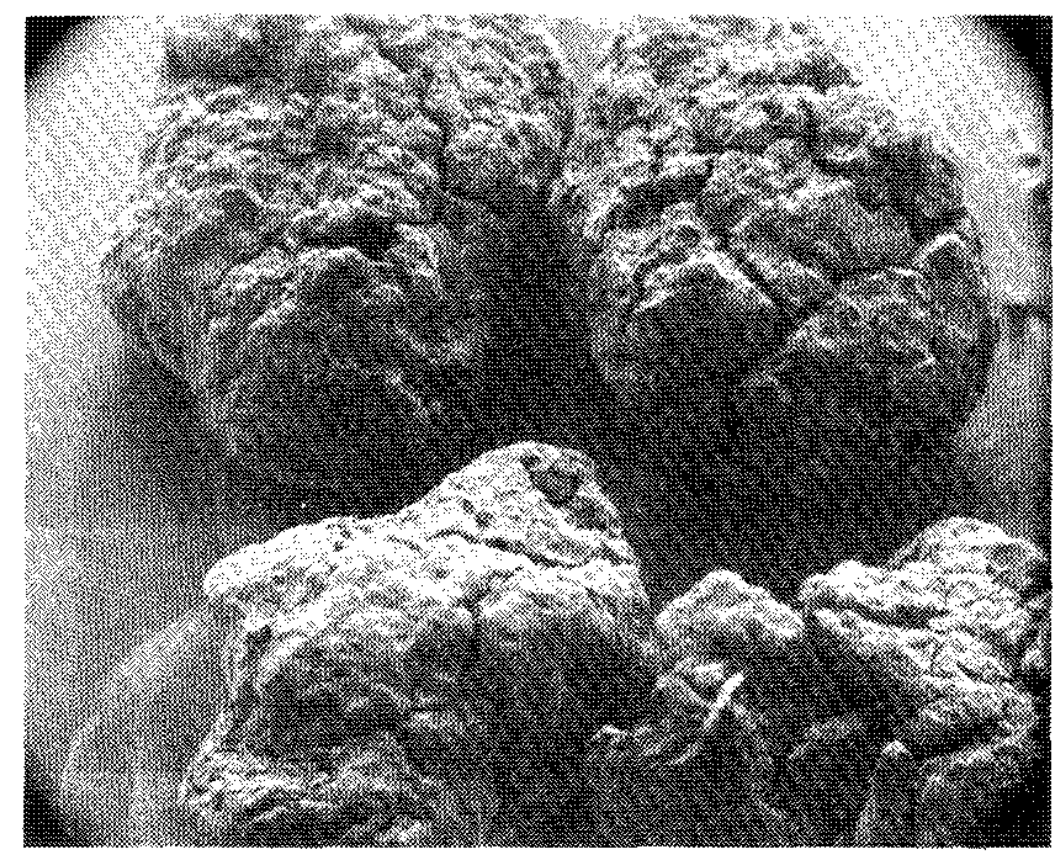

FIGURE 9. Petroleum-Base Carbon, 20X

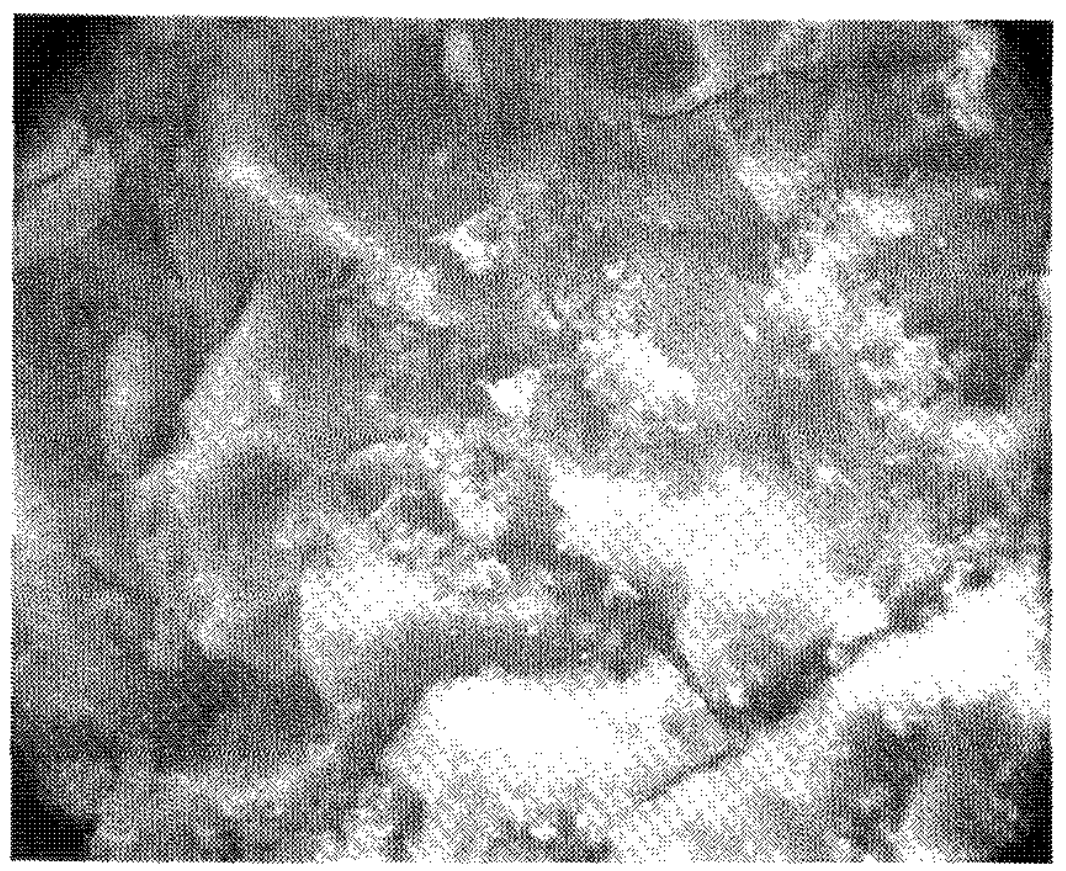

FIGURE 10. Petroleum-Base Carbon, 1000X 


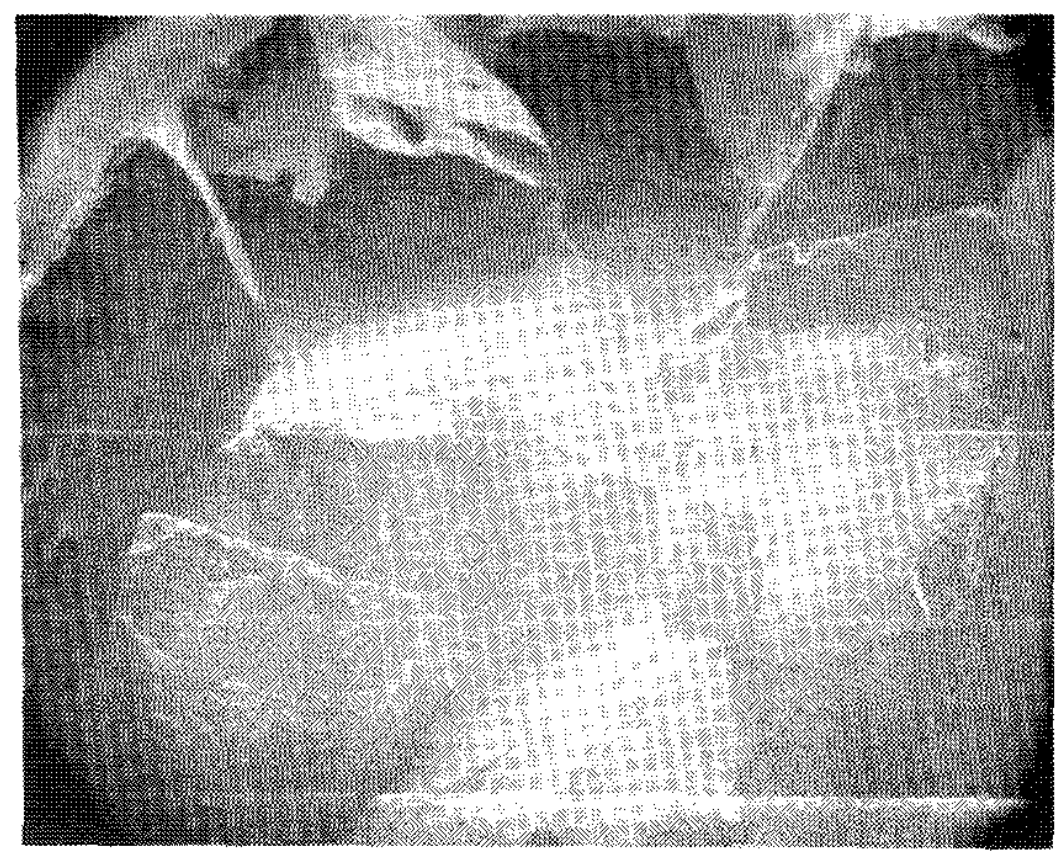

FIGURE 11. Coconut-Base Carbon $\left(1000 \mathrm{~m}^{2} / \mathrm{g}\right), 20 X$

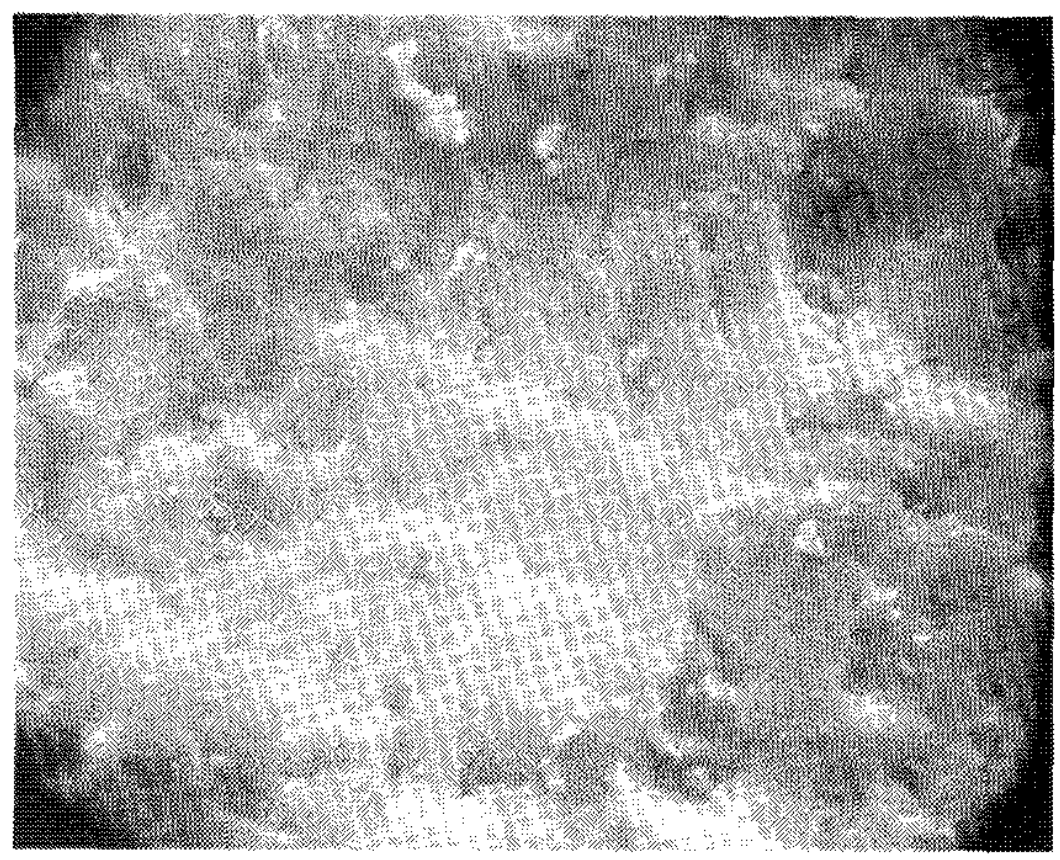

FIQURE 12. Unimpregnated Coconut-Base Carbon $\left(1000 \mathrm{~m}^{2} / \mathrm{g}\right), 1000 \mathrm{x}$ 


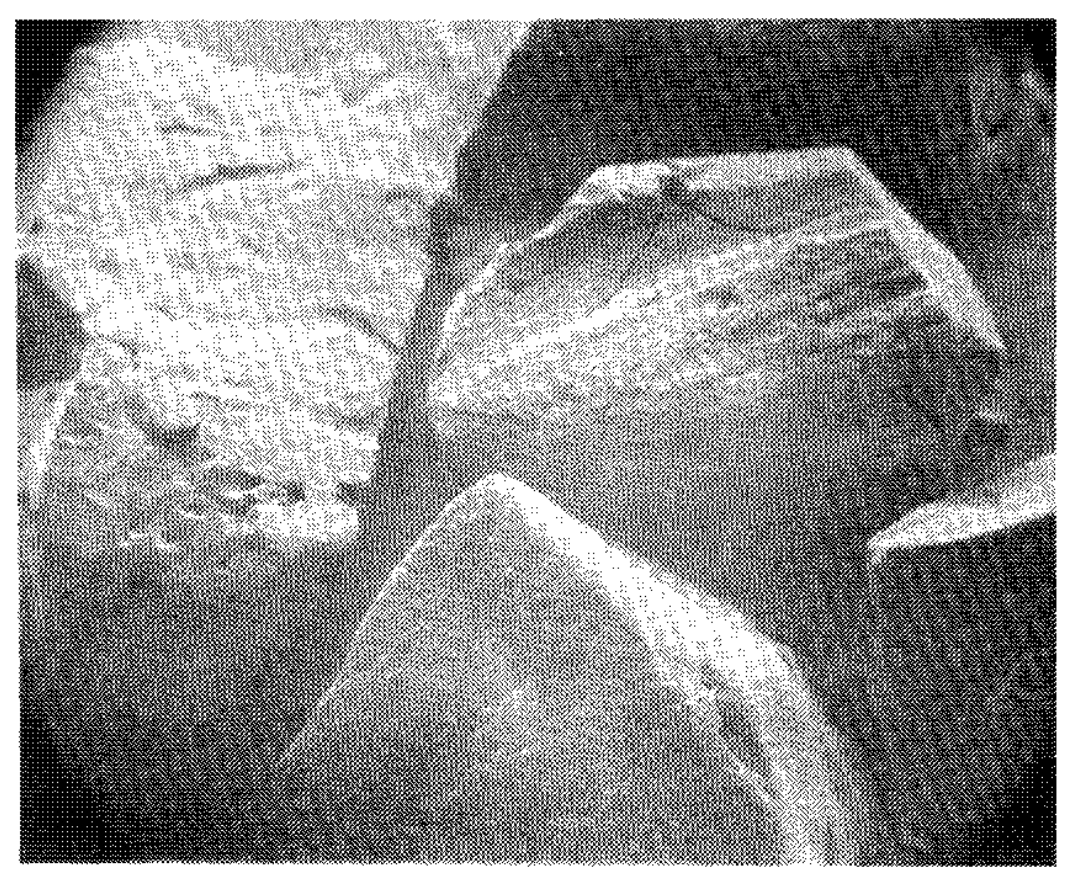

FIGURE 13. Coconut-Base Carbon $\left(1700 \mathrm{~m}^{2} / 9\right), 20 x$

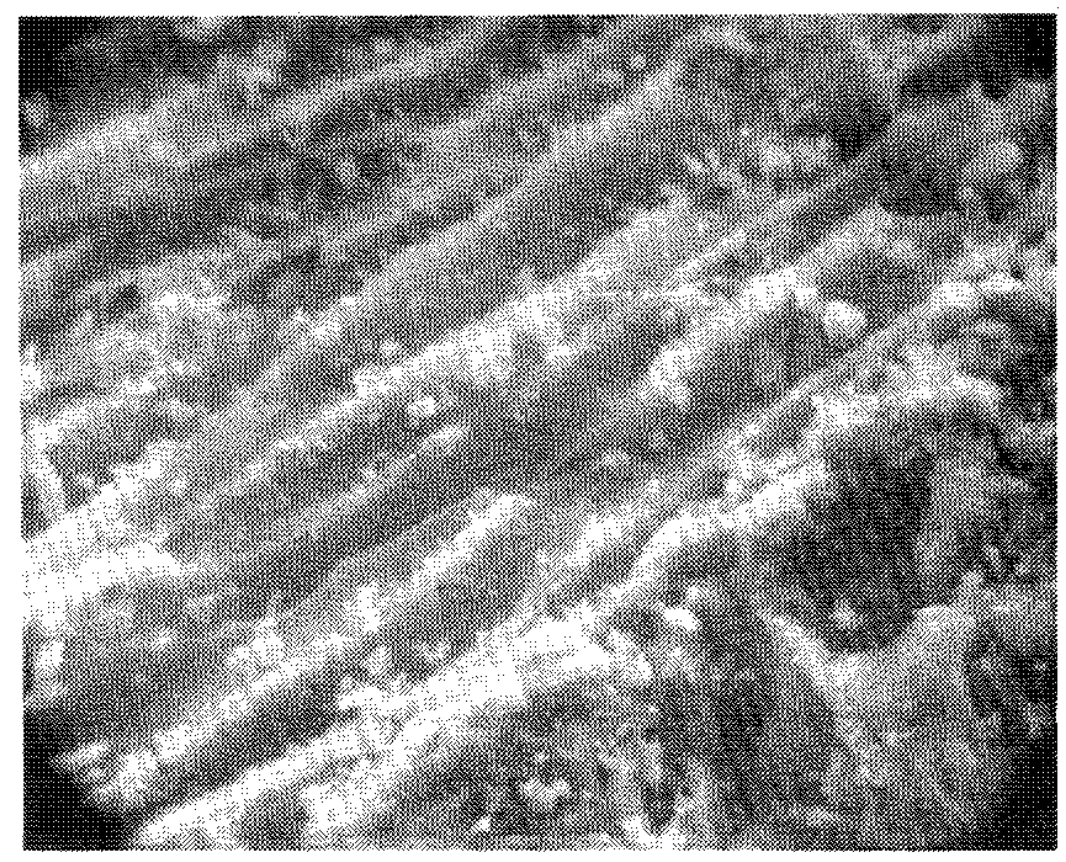

FIguRE 14. Coconut-Base Carbon $\left(1700 \mathrm{~m}^{2} / \mathrm{g}\right), 1000 x$ 


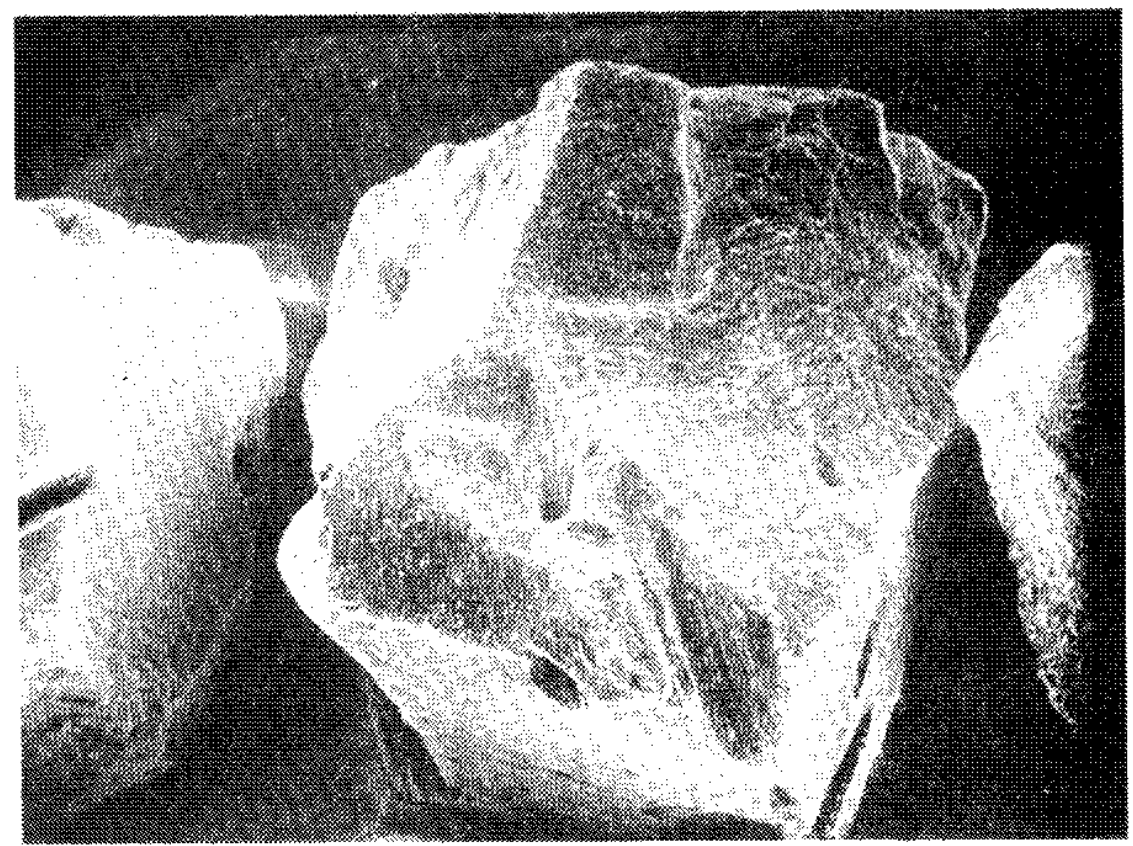

FICURE 15. Hole in Coconut Carbon (1000 mi/g), 50X

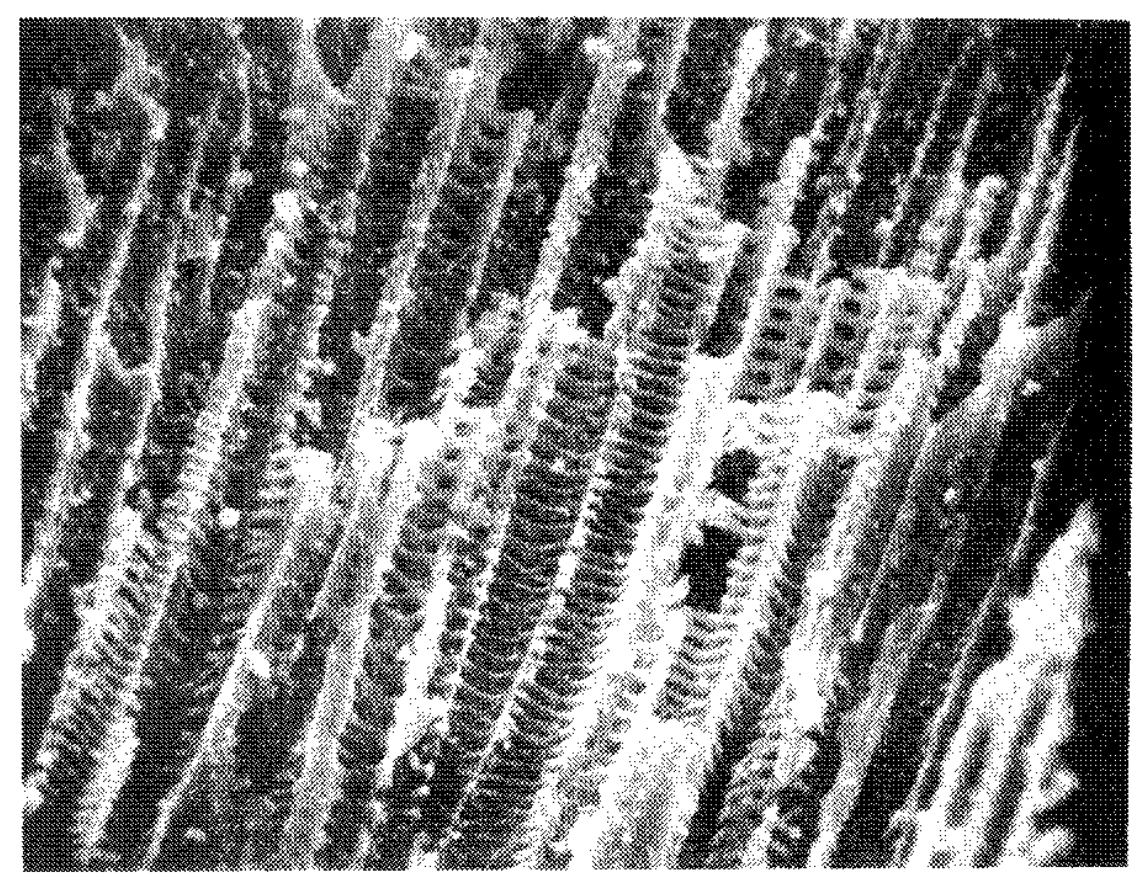

Froune 6. Coconut Carbon Rib Structure in Hole. nowox 


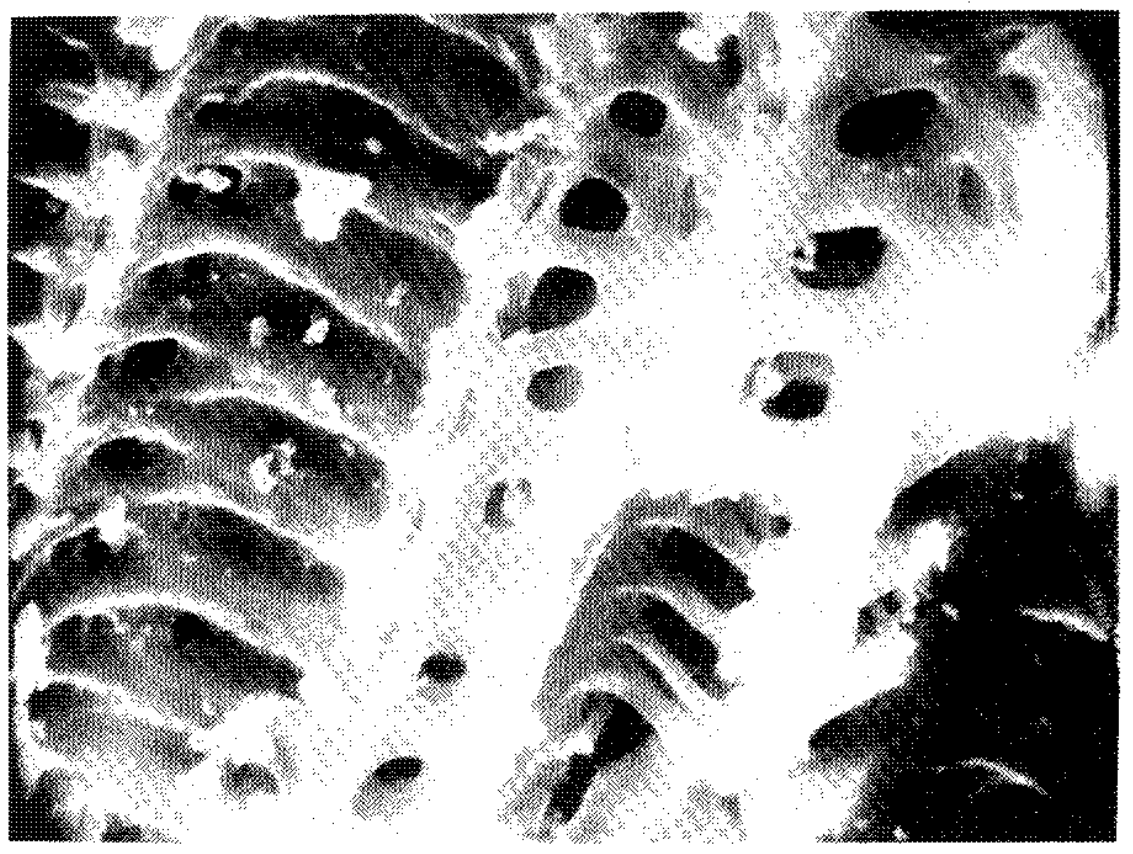

FIGURE 17. Detail of Coconut Rib Structure, $5000 \mathrm{x}$

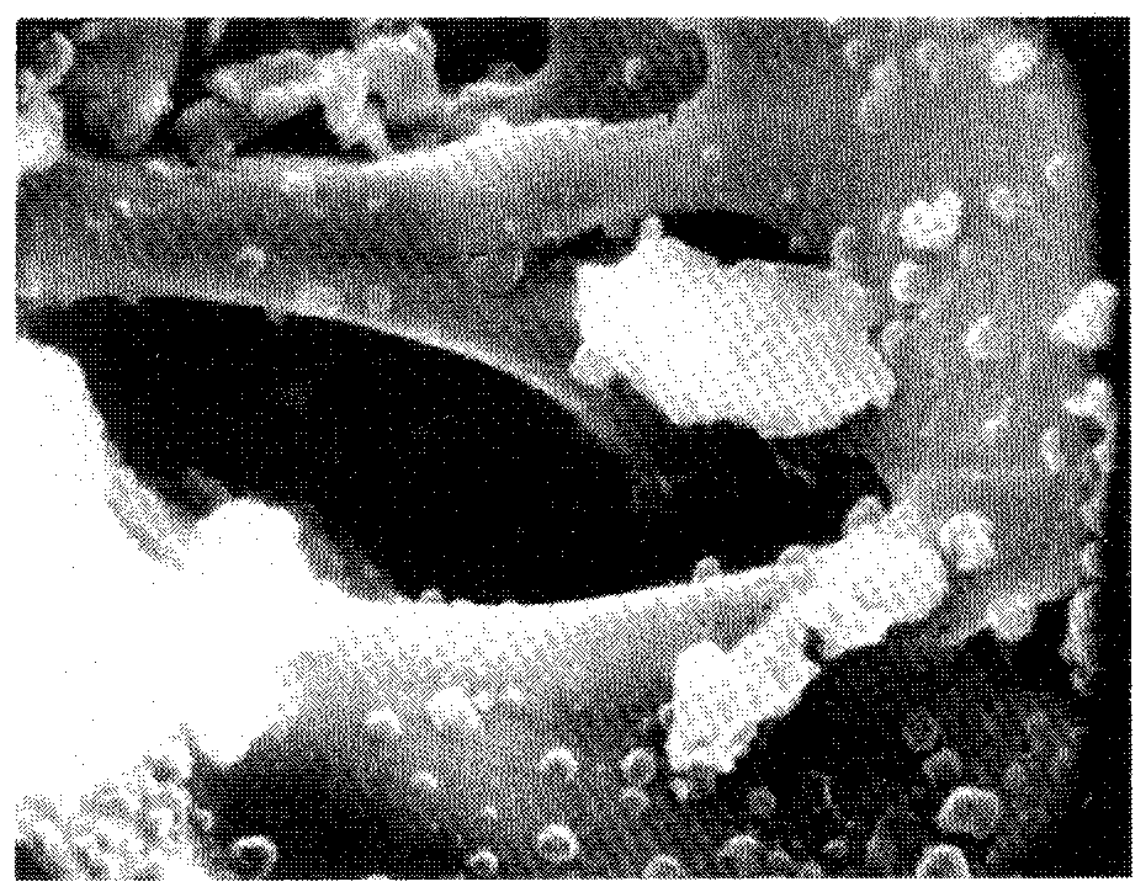

FIQURE 18. Porosity of Coconut Carbon Rib Structure, $20,000 x$ 
on either face. A 6-inch column of water was then supported by the exposed media until a drop of water penetrated the media. The time required for water to penetrate the media is a measure of the relative water repellency.

Water repellency of each media was measured as a function of gamma exposure as shown in Figure 19. Media A, B, and C deteriorated at lower gamma exposures than Media D, E, and F. Water penetration in 5 to 6 seconds indicated complete 1 oss of water repellency for all media. Media $C$ had poor water repellency even when unirradiated, and the inconsistent data indicated nonuniform waterproofing treatment. Samples with water penetration times of 60 to 100 seconds absorbed a drop of water placed on the surface of the media in 1 to 3 minutes. Samples with penetration time less than 10 seconds absorbed the water drop instantly.

Immediately after the first drop of water penetrated the media, the water column height was increased at the rate of 1 inch every 5 seconds until the media ruptured. The height of the water column required to rupture the media is a measure of the relative wet strength.

Wet strength of each media was measured as a function of gamma exposure (Figure 20). Data shown at zero gamma exposure were measured as discussed previously, except that these samples were ruptured with no water drop penetration. These data do not represent wet strength in the same sense as data for irradiated samples because the media was not wetted before rupture.

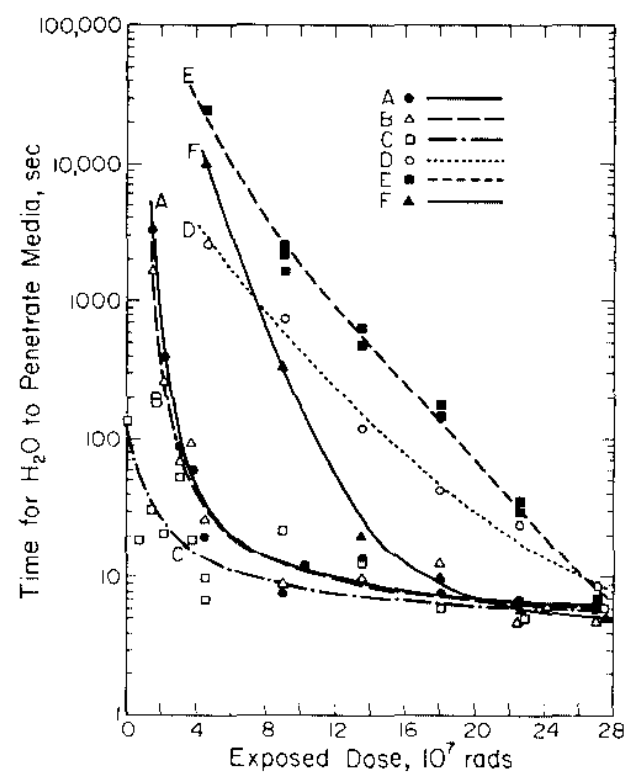

FIGURE 19. HEPA Filter Media $\mathrm{H}_{2} \mathrm{O}$ Repellancy vs Exposed Gamma Dose 


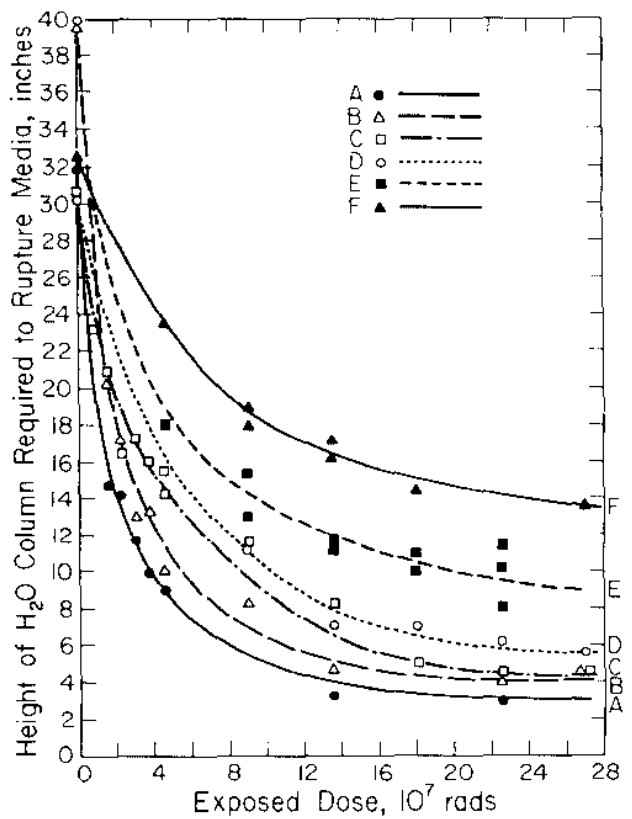

FIGURE 20. HEPA Filter Wet Strength vs Exposed Gamma Dose

The media did not change in appearance, except for slight yellowing of Media $C$. Other properties were measured before and after exposure to $5 \times 10^{7}$ rads for all media except $E$. Data shown in Table VI indicate a range of properties for the several commercial filter media tested. The results have not been related to differences in the products, nor has a suitable performance index been established.

TABLE VI

HEPA Filter Irradiation Summary

HEPA filter Media

Exposed gamma dose, rads Basis weight, $1 \mathrm{~b} / 3000 \mathrm{ft}^{2}$ :a Moisture content, wt weight loss after combustion, wt $x$

Thickness, mils ${ }^{2}$

DOP penetration at

$14.2 \mathrm{~cm} / \mathrm{sec}$, z $x$

Flow resistance at

$14.2 \mathrm{~cm} / \mathrm{sec}, \mathrm{mm} \mathrm{H} \mathrm{H}_{2} \mathrm{O} \approx$

Tersile strength of 1 -

inch-wide strip in

machine (longitudinal)

direction, $l b / i n a$

Tensile strength of 1-

inch-wide strip in

cross direction, $1 b /$ in $^{a}$

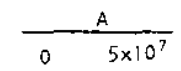

$61.2 \quad 61.0$

$\begin{array}{ll}0.8 & 1.7\end{array}$

$3.0 \quad 1.5$

$15.5 \quad 15.5$

$0.008 \quad 0.012$

$39 \quad 39$

$\begin{array}{lll}5.5 & 2.9 & 7.7\end{array}$

$\begin{array}{lll}3.2 & 2.1 \quad 3.2\end{array}$

3.9

37

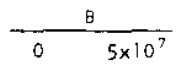

$52.7 \quad 52.3$

$0.3 \quad 2.0$

2.8

14

$0.018 \quad 0.022$

36

$\begin{array}{lll}3.5 & 3.7 & 2.2\end{array}$

4

$\begin{array}{llll}3.1 & 3.0 & 4.0 & 3.0\end{array}$

For difinition of terms see Reference 12. 


\section{Simuzated Accident Performance}

Media $E$ was used in the irradiation test section to simulate performance of HEPA filters in Savannah River facilities. A portion of media was exposed to $\sim 2.3 \times 10^{8}$ rads during a normal test, while other portions received less exposures because of the gamma field gradient across the HEPA filter module of the test section. Wetting of portions of the media in the greatest field has been observed following $100 \%$ relative humidity tests, but no rupture has occurred.

\section{Media Contaminated During Source Rod Incident}

Beta and gamma radiation exposure to filter components in the $\mathrm{K}$ reactor confinement system resulted from trapping antimony and tellurium activity released from an antimony-beryllium neutron source rod, which melted while suspended in air in the $K$ reactor room on November 9, 1970. A detailed description of this incident is reported in References 13 and 14 . The calculated radiation dose rates to "Demisters" and HEPA filters at the time of the incident (November 9, 1970) and integrated radiation doses ( $\sim 80 \%$ beta, $20 \%$ gamma) to May 1, 1972 are shown in Table VII. Isotopic activities were calculated from radiation measurements from filter samples. It was assumed that $100 \%$ of the beta energy and $5 \%$ of the gamma energy were absorbed in filter component materials.

On March 21, 1972, samples of "Demister" media, HEPA filter media, and activated carbon were removed from the most highly contaminated of the four confinement compartments and examined for radiation degradation. Based on doses in Table VII and exposures of unused HEPA media in the ${ }^{60} \mathrm{Co}$ gamma field, no damage to the $\mathrm{K}$ reactor HEPA filters would be expected. Water repellency of the contaminated media was measured and compared with water repellency

TABLE VII

Filter Units Contaminated in Antimony Source Rod Incident $B, Y$ Dose Rate and Integrated Dose

Confinement Compartment

K2

K3

K5

K6

\begin{tabular}{|c|c|c|}
\hline \multicolumn{3}{|c|}{ Moisture Separators } \\
\hline $\mathrm{rad} / \mathrm{hr}$ & $(11-9-70)$ & $\operatorname{rads}(5-1-72)$ \\
\hline & 949 & $6.9 \times 10^{5}$ \\
\hline & 1011 & $7.3 \times 10^{5}$ \\
\hline & 97 & $7.1 \times 10^{4}$ \\
\hline & 6.3 & $4.5 \times 10^{3}$ \\
\hline
\end{tabular}

$6.34 .5 \times 10^{3}$

\begin{tabular}{|c|c|}
\hline (11-9-70) & rads $(5-1-72)$ \\
\hline 8270 & $6.0 \times 10^{6}$ \\
\hline 8890 & $6.4 \times 10^{5}$ \\
\hline 847 & $6.1 \times 10^{5}$ \\
\hline 54 & $3.9 \times 10^{4}$ \\
\hline
\end{tabular}


of used media with longer service in Savannah River confinement facilities but with no contamination or incident history. The contaminated media showed some loss of water repellency and wet strength, but the material with normal service was less water repellent than the contaminated media. Deterioration of SRP HEPA filters increased with increased service age. Water repellency data are shown in Table VIII. Degradation of the contaminated HEPA media is most likely a result of normal service exposure rather than radiation damage.

\section{TABLE VHI}

Water Repellency of Media with Service in Confinement System (No Radiation Exposure)

\begin{tabular}{lrc}
$\begin{array}{c}\text { Service, } \\
\text { Months }\end{array}$ & $\begin{array}{c}\text { Time for } \mathrm{H}_{2} \mathrm{O} \text { to } \\
\text { Penetrate Media }\end{array}$ & $\begin{array}{c}\text { Height of } \mathrm{H}_{2} \mathrm{O} \text { Column } \\
\text { Requi red to Rupture } \\
\text { Media, inches }\end{array}$ \\
\cline { 2 - 2 } & $>48 \mathrm{hr}$ & 39.5 \\
4 & $>4 \mathrm{hr}$ & 32.5 \\
7 & $>4 \mathrm{hr}$ & 28.0 \\
11 & $209 \mathrm{sec}^{a}$ & $6.7^{a}$ \\
13 & $66 \mathrm{sec}^{a}$ & $15.0^{a}$ \\
48 & $57 \mathrm{sec}^{a}$ & $10.4^{a}$ \\
\hline Average of 10 tests & &
\end{tabular}

\section{Normal Service Deterioration}

Deterioration of HEPA filter media with normal service is being investigated. Three-inch diameter samples of HEPA filter media were exposed to flow of saturated air (dew point $30^{\circ} \mathrm{C}$ ) at a face velocity of $3 \mathrm{ft} / \mathrm{min}$ for 8 hours to observe blinding of media as a function of flow exposure time (Figure 21). A1so shown for comparison are data on unused unirradiated media and unused media exposed to $1.8 \times 10^{8}$ rads in the ${ }^{60} \mathrm{Co}$ gamma field.

A black soot accumulates on HEPA filters as service in the confinement system increases. Blinding of used media with moisture during saturated air flow tests correlates closely with the quantity of soot deposited on the media. Deterioration of water repellency also correlates more closely with soot loading on the media than with actual service age. Behavior of media with 7 months and 48 months service is compared in Figure 21 . The 7-month service media has a light soot loading and retains 


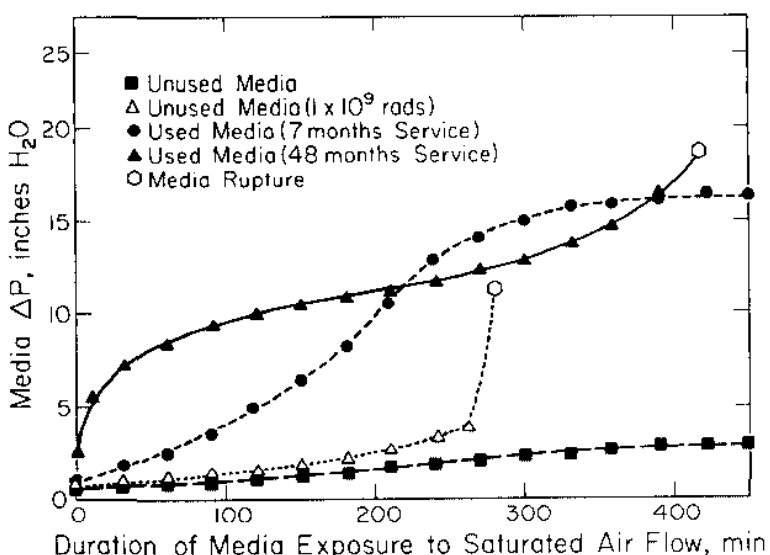

FIGURE 21. Exposure of SRP HEPA Filter Media to Saturated Air Flow

its water repellency as indicated by gradual blinding and no continuing increase in $\Delta \mathrm{P}$ to rupture. The 48-month-service media has a heavier soot layer and shows rapid blinding of the soot layer followed by blinding of the media and rupture.

Treatment of unused media with a solution of the black soot in ethyl alcohol destroyed the water repellency of the unused media. Treatment with alcohol alone had no effect; thus, a contaminant in the soot may be reacting with the waterproofing agent in the media. Chemical analysis of the soot is expected to identify contaminants that might react with the waterproofing agent.

\section{Electron Microscope Examination}

Figure 22 shows scanning electron micrographs of unused unirradiated HEPA filter media (top row) and unused media exposed to $1 \times 10^{9}$ rads in a $4.5 \times 10^{7} \mathrm{rad} / \mathrm{hr}$ gamma field. The irradiated material appears to show some loss of binder between the glass fibers at a magnification of 2600 . At magnifications of 6000 and greater, small blisters can be observed on the surfaces of the glass fibers of the unirradiated media. No such blisters were observed on the irradiated material. The blisters may indicate a coating of waterproofing agent on the fibers. Lack of blisters in irradiated media may indicate an absence of waterproofing agent.

Figure 23 shows media with $\checkmark 48$ months service in Savannah River confinement facilities. Both the upstream side of the media covered with the black soot layer (top row) and the downstream or clean side of the media (bottom row) are shown. The soot particles clearly appear to be attached to the surface 

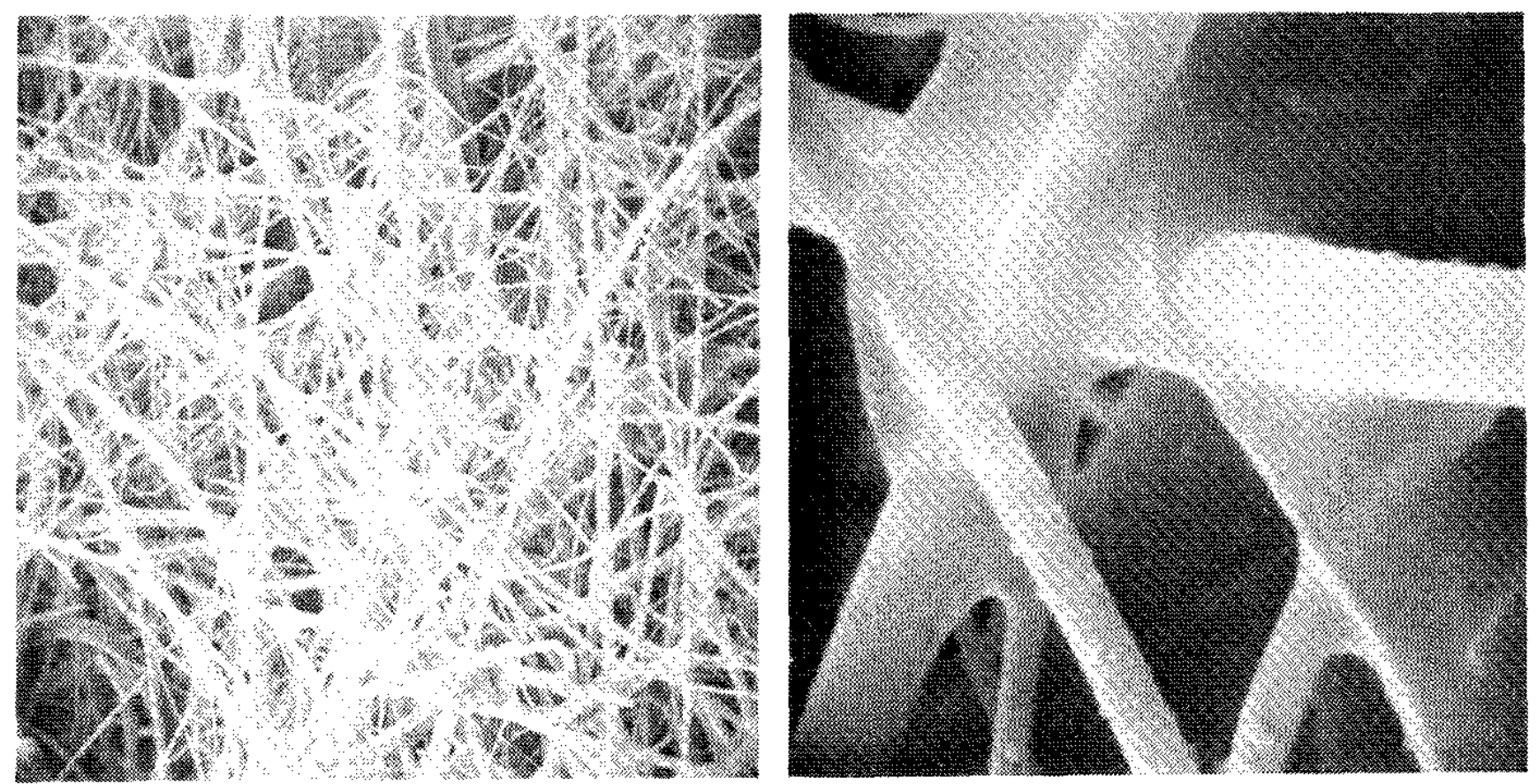

$590 x$

Unirradiated

$11700 x$
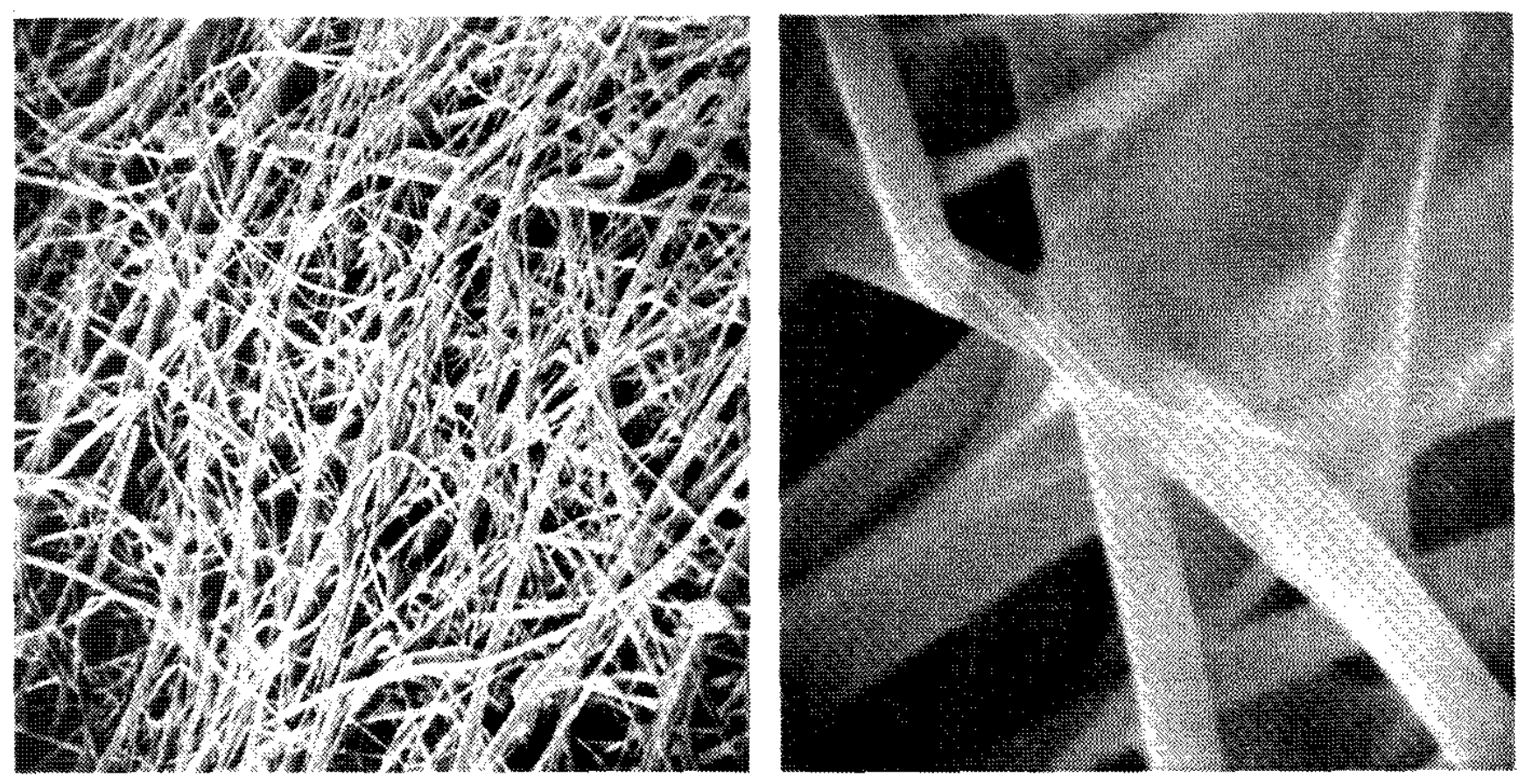

$620 x$

Irradiated

$12300 x$

FIGURE 22. Scanning Electron Microscope Examination of Irradiated HEPA Filter Media 

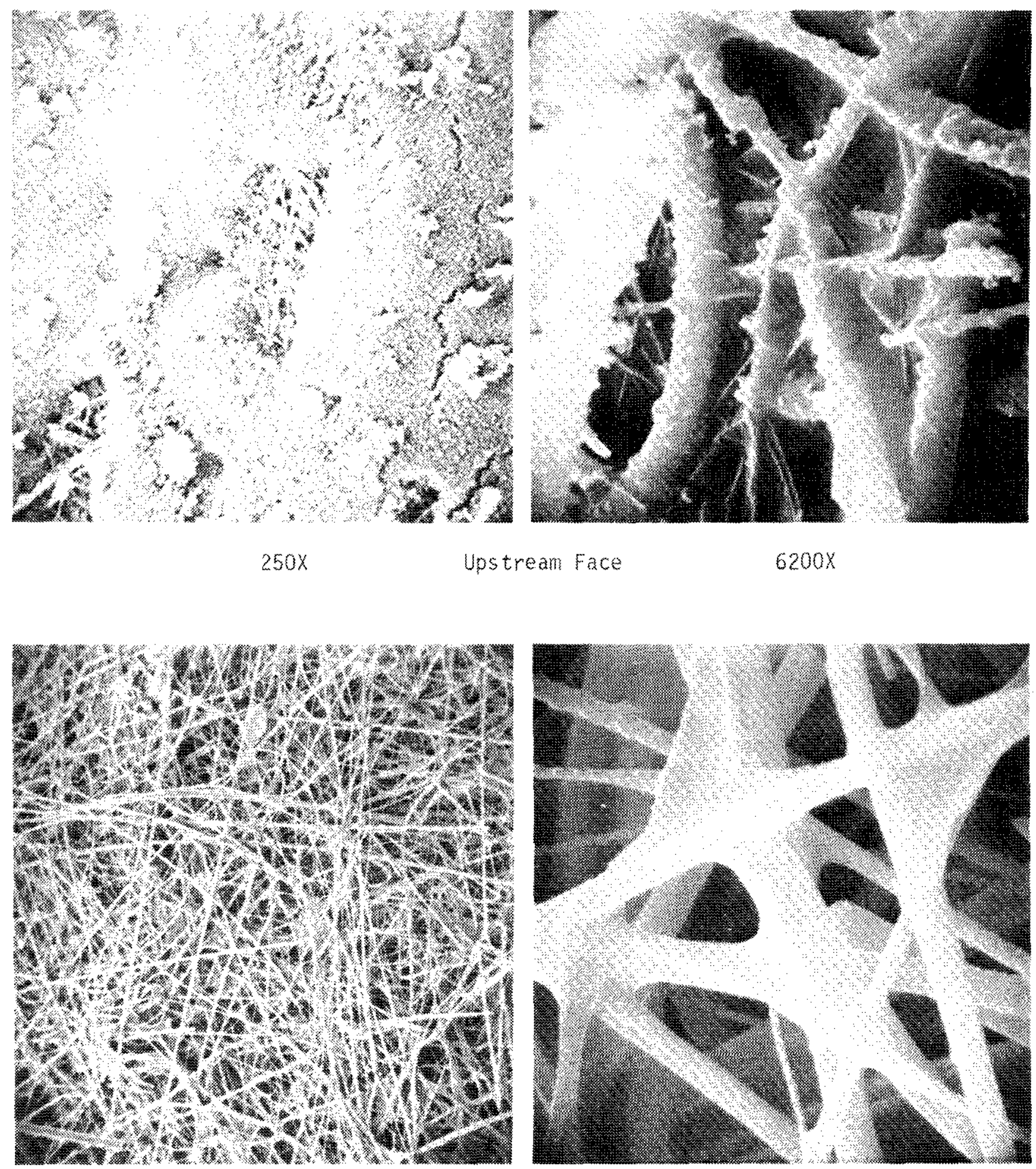

$235 x$

Downstream Face

$5900 x$

FIQURE 23. Scaming Electron Microscope Examination of Used Heph Filter Media 
coating of binder on the glass fibers and are small enough to migrate through the media. Simple migration and absorption of these hydrophylic particles may be creating a rough coating over the waterproofing agent thus rendering the media non-waterrepellent to the depth of migration of the soot particles. No significant erosion of the binder from 48 months of air flow is apparent.

\section{Moisture Separator Material}

$$
\text { "T"eflon"-Stainless Steel "Demister" }
$$

Samples of moisture separator material made of "Teflon"coated stainless steel were irradiated to various exposures in a gamma field of $4.5 \times 10^{7}$ rads. No degradation was observed at exposures less than $2 \times 10^{7}$ rads. The "Teflon" fibers disintegrated at greater exposures. Figure 24 shows a sample of unirradiated material (left) and a sample of material exposed to $2.4 \times 10^{8}$ rads (right). The "Teflon" fibers were shaken from part of the irradiated sample leaving only the stainless steel mesh.

"Teflon"-coated stainless steel material is used in the irradiation test section to simulate performance of "Teflon"-stainless steel moisture separators in Savannah River confinement facilities. Tests have been run in which this material was exposed to $\sim 4 \times 10^{7}$ rads, while a steam-air mixture at $80^{\circ} \mathrm{C}$ and $100 \%$ relative humidity flowed through the material. "Teflon" fibers were found in the condensate removed by the moisture separator from the flowing air stream, but no gross damage to the material was observed.

"Teflon"-stainless steel moisture separators in the $\mathrm{K}$ reactor confinement system received beta and gamma radiation doses shown in Table VII from antimony and tellurium contamination. Based on these doses and exposure of unused material in the ${ }^{60} \mathrm{Co}$ gammia field, no damage to the $K$ reactor moisture separators would be expected. When contaminated and uncontaminated material with normal service were irradiated simultancously in the ${ }^{60} \mathrm{Co}$ gamma field, both materials were damaged similarly at ${ }^{60} \mathrm{Co}$ exposures of $2 \times 10^{7}$ and $5 \times 10^{7}$ rads indicating that the exposure from antimony was negligible compared to the exposure from ${ }^{60} \mathrm{Co}$.

\section{Glass Fiber Demister}

Samples of a glass fiber moisture separator material (not used at SRP) were exposed to $2.4 \times 10^{8} \mathrm{rads}$ in a $4.5 \times 10^{7} \mathrm{rad} / \mathrm{hr}$ gamma field. An unirradiated sample (left) and an irradiated sample (right) are shown in Figure 25. The glass fiber material appeared unaffected following the radiation exposure. 

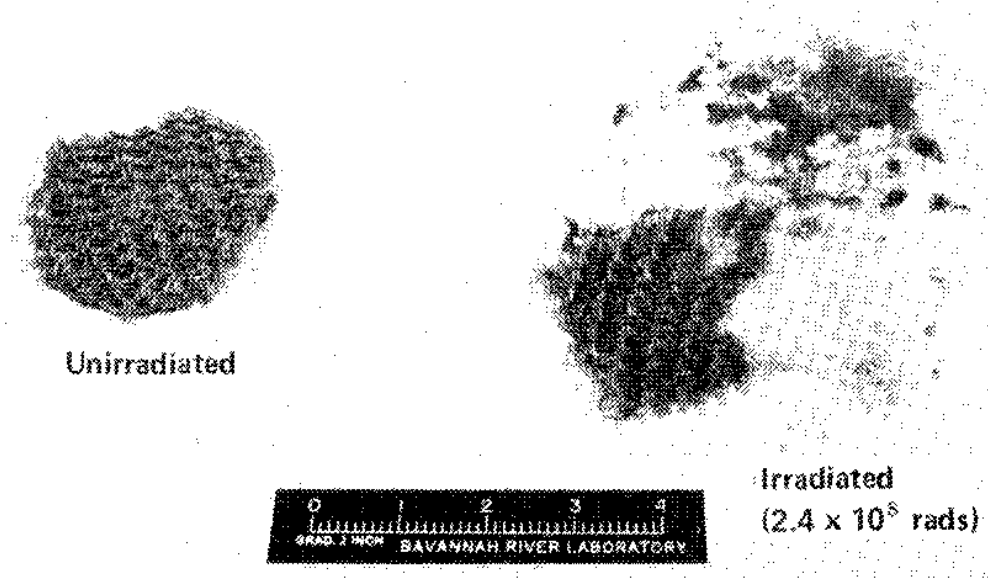

FIGURE 24. "Teflon" and Stainless Steel "Demister" Material

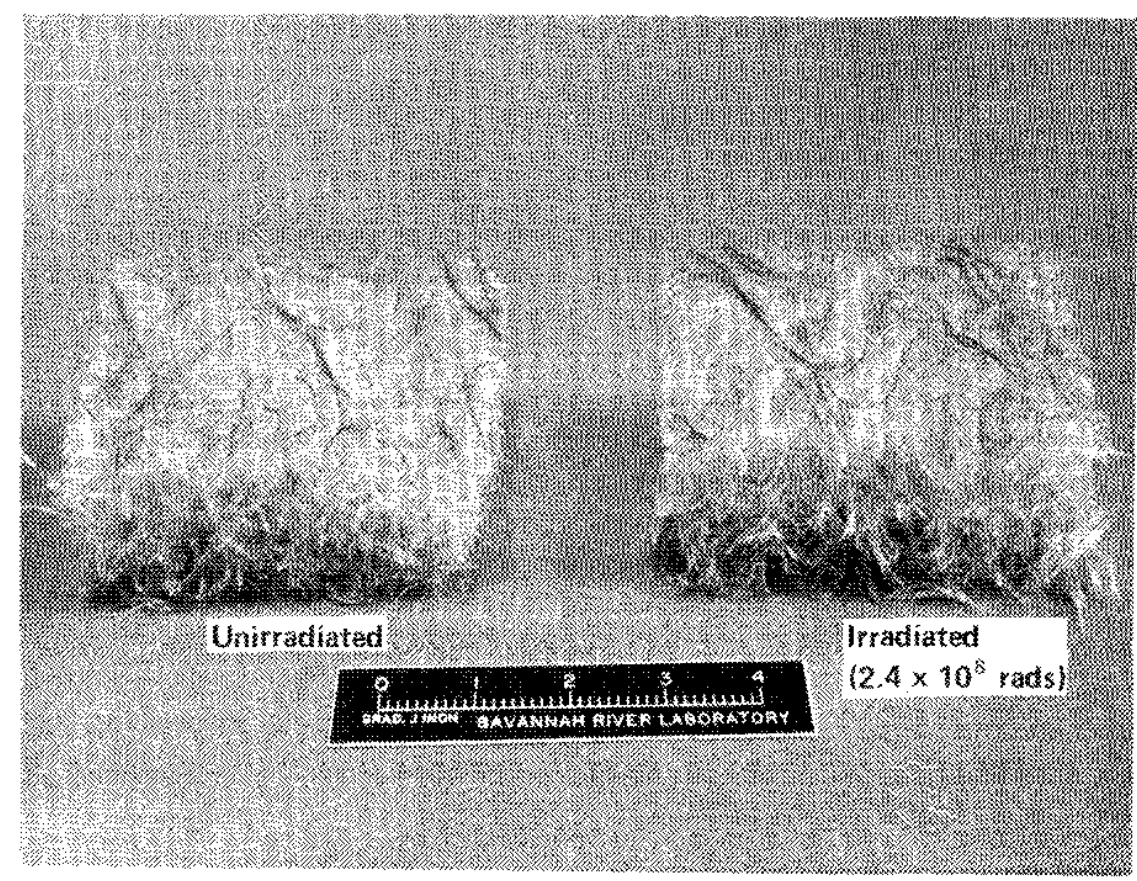

FuURE 25. Glass Fiber "Demister" Material 
Gasketing Material

\section{Sponge Neoprene}

Samples of closed-cell neoprene sponge of the type used to seal filters to installation frames were irradiated to various exposures in a gamma field of $4.5 \times 10^{7} \mathrm{rad} / \mathrm{hr}$. Figure 26 shows an unirradiated sample (top) and an irradiated sample (bottom) exposed to $9 \times 10^{8} \mathrm{rads}$. The irradiated material was extremely brittle at this exposure and could be crumbled into small particles, which had the appearance of charcoal. The material hardened at lesser exposures (Figure 27). At exposures greater than $4 \times 10^{8}$ rads, hardness measurement caused permanent deformation of the material surface, and the measurement was considered invalid. Shore hardness of gasketing materials was measured with a Clarkstan rubber hardness gauge.

A one-half-inch wide neoprene sponge gasket is used in the confinement system irradiation test section to simulate performance of gaskets that seal carbon beds in SRP confinement facilities. In several tests, this gasket was exposed to $\sim 3 \times 10^{8}$ rads before injecting iodine into the system. The efficiency of the system for removing iodine from the flowing air stream was consistent with the established efficiency of the activated carbon used. Thus, no gasket leakage occurred. The gaskets were compressed to $250 \%$ of their original thickness during these tests and were found to be permanently deformed following their irradiation.

\section{Silicone Gasketing Grease}

Because neoprene sponge gaskets deform permanently and lose their compressibility when tightly compressed for several months in filter installations, silicone gasketing grease $h_{c}$. bt. sn suggested as a possible substitute for the sponge neopr s material. Two types of silicone grease were irradiated in a gamma field of $4.5 \times 10^{7} \mathrm{rad} / \mathrm{hr}$. Samples of the unirradiated grease (top) and samples exposed to $9 \times 10^{7} \mathrm{rads}$ (middle) and $v 3 \times 10^{9}$ rads (bottom) are shown in Figure 28. Both types of grease hardened into a silicone rubber with extensive void formations. The formation of voids was a result of increasing the temperature of the material to $\sim 140^{\circ} \mathrm{C}$ during irradiation because of gamma absorption. When the material was heated in an oven to $140^{\circ} \mathrm{C}$, similar voids formed but no hardening occurred. With increased exposure both materials crystallized into a flakey powder resumbling mica and darkened in color slightly.

Figure 29 shows Shore hardness of both silicone greases as a function of gamma exposure. Inconsistencies in hardness measurements were caused by the voids in the material. Each data point 


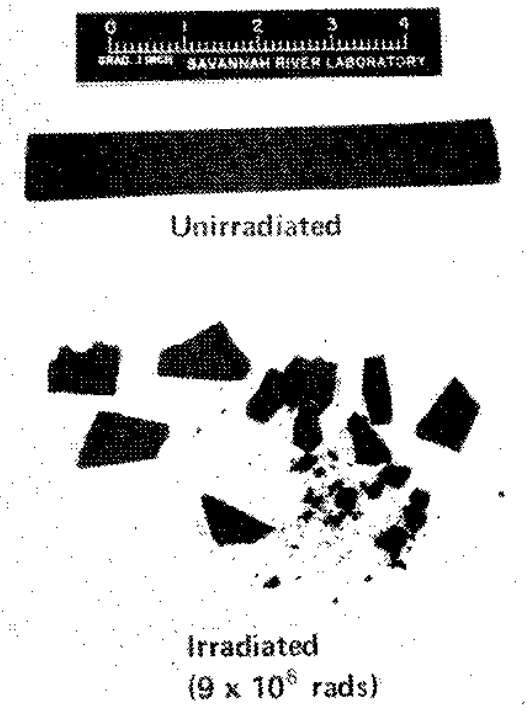

FIGURE 26. Neoprene Sponge Gasket Samples

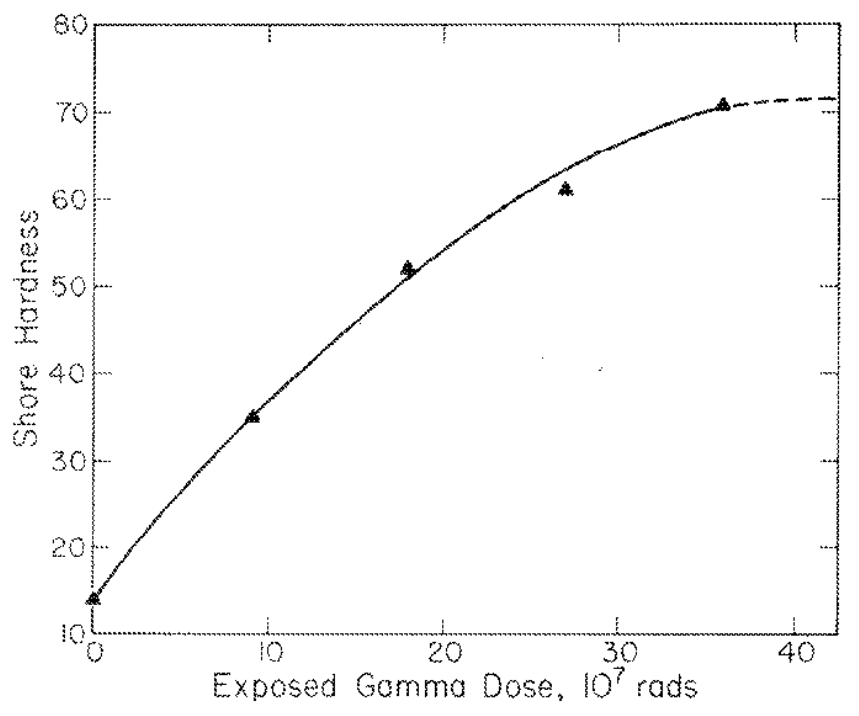

FIGURE 27. Shore Hardness of Sponge Neoprene Gasket vs Exposed Gamma Dose 


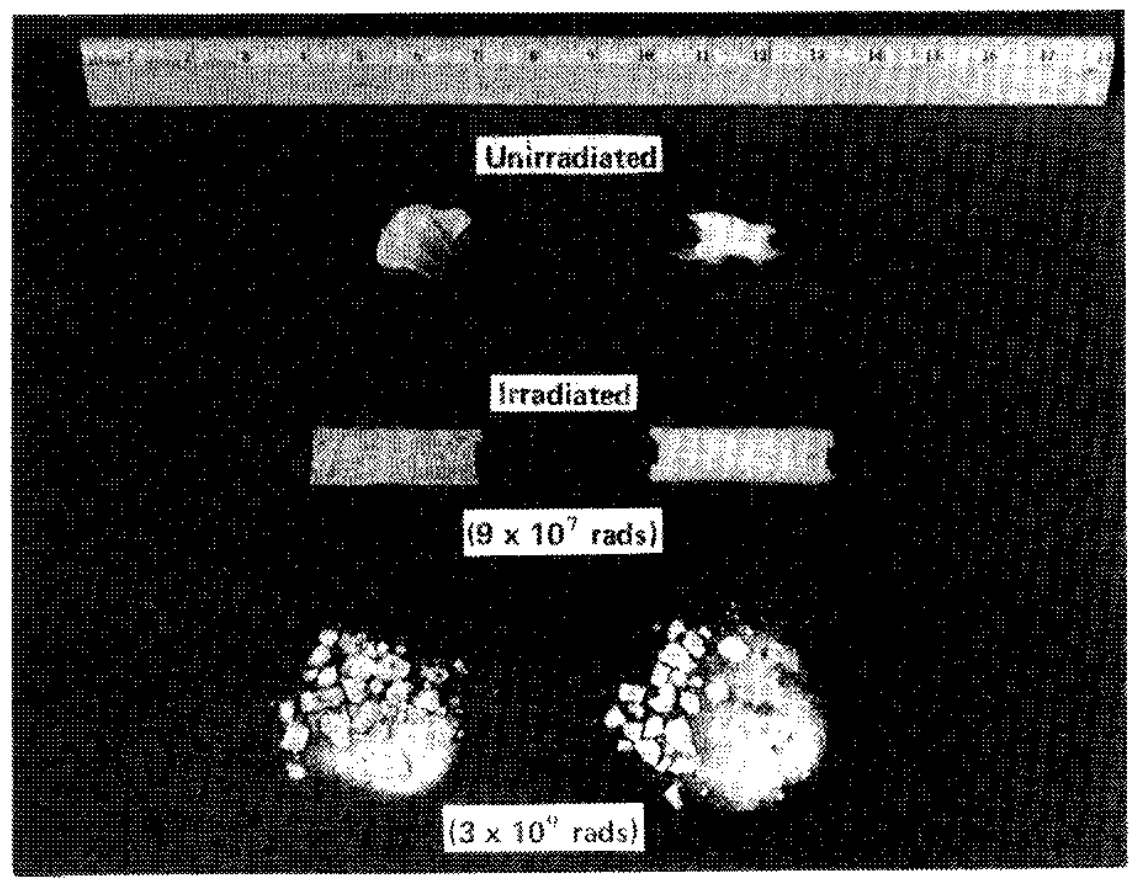

FIGURE 28. Silicone Grease Samples

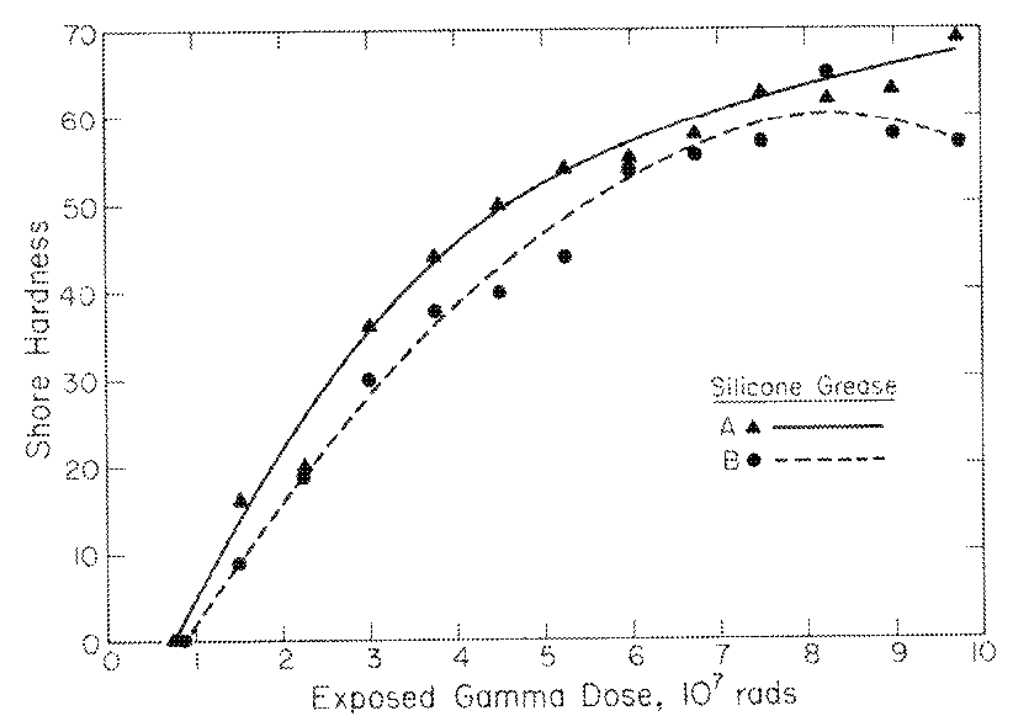

FrGURE 29. Shore Hardness of Silicone Gasketing Grease vs Exposed Gamma Dose 
in Figure 25 is an average value for four measurements made on a sample. At exposures greater than $\sim 1 \times 10^{8}$ rads, hardness measurement caused permanent deformation of the material surface, and the measurement was considered invalid.

\section{Filter Construction Materials}

Two samples of asbestos separator material used in some HEPA filters (not used at SRP) were exposed to $\sim 5 \times 10^{7} \mathrm{rads}$ in a $1.7 \times 10^{7} \mathrm{rad} / \mathrm{hr}$ gamma field (Figure 30 bottom row). Unirradiated materials are also shown for comparison (top row). Material appearance or color did not change after irradiation. Physical properties of the materials were measured before and after irradiation and are summarized in Table IX. Df the properties measured, only moisture content was significantly affected by the radiation exposure.

Samples of rubber-base and foam adhesives used in the construction of various types of HEPA filters (not used at SRP) were irradiated (Figure 31). Metal strips ( 1 inch wide) were bonded together with each type of adhesive. The bond strength of each adhesive was then measured at the Naval Research Laboratory with no radiation exposure and on samples which had been exposed to $25 \times 10^{7} \mathrm{rads}$ in a $1.7 \times 10^{7} \mathrm{rad} / \mathrm{hr}$ gamma field. The samples in Figure 31 are shown after bond strength tests. Samples in the top row received no radiation exposure. Samples in the bottom row were irradiated. Bond strength data are shown in Table $X$.

Adhesives $\mathrm{A}$ and $\mathrm{C}$ darkened after irradiation. Adhesives $\mathrm{B}$ and $C$ showed good bonding to surfaces, although Adhesive $C$ lost some bond strength. Adhesive A would not bond after irradiation and separated easily from the metal surface as shown in Figure 31.

Samples of plywood and particle board of the type used as framing material for some HEPA filters were supplied by the AEC Division of Operational Safety and were exposed to $\sim 5 \times 10^{7}$ rads in a gamma field of $1.7 \times 10^{7} \mathrm{rad} / \mathrm{hr}$. Both materials appeared unchanged except for slight discoloration and bakeout of impregnant. Additional samples were exposed to $\sim 3 \times 10^{9}$ rads in a $4.5 \times 10^{7} \mathrm{rad} / \mathrm{hr}$ field. These irradiated materials became crumbly and brittle with darkening in color (Figure 32). 


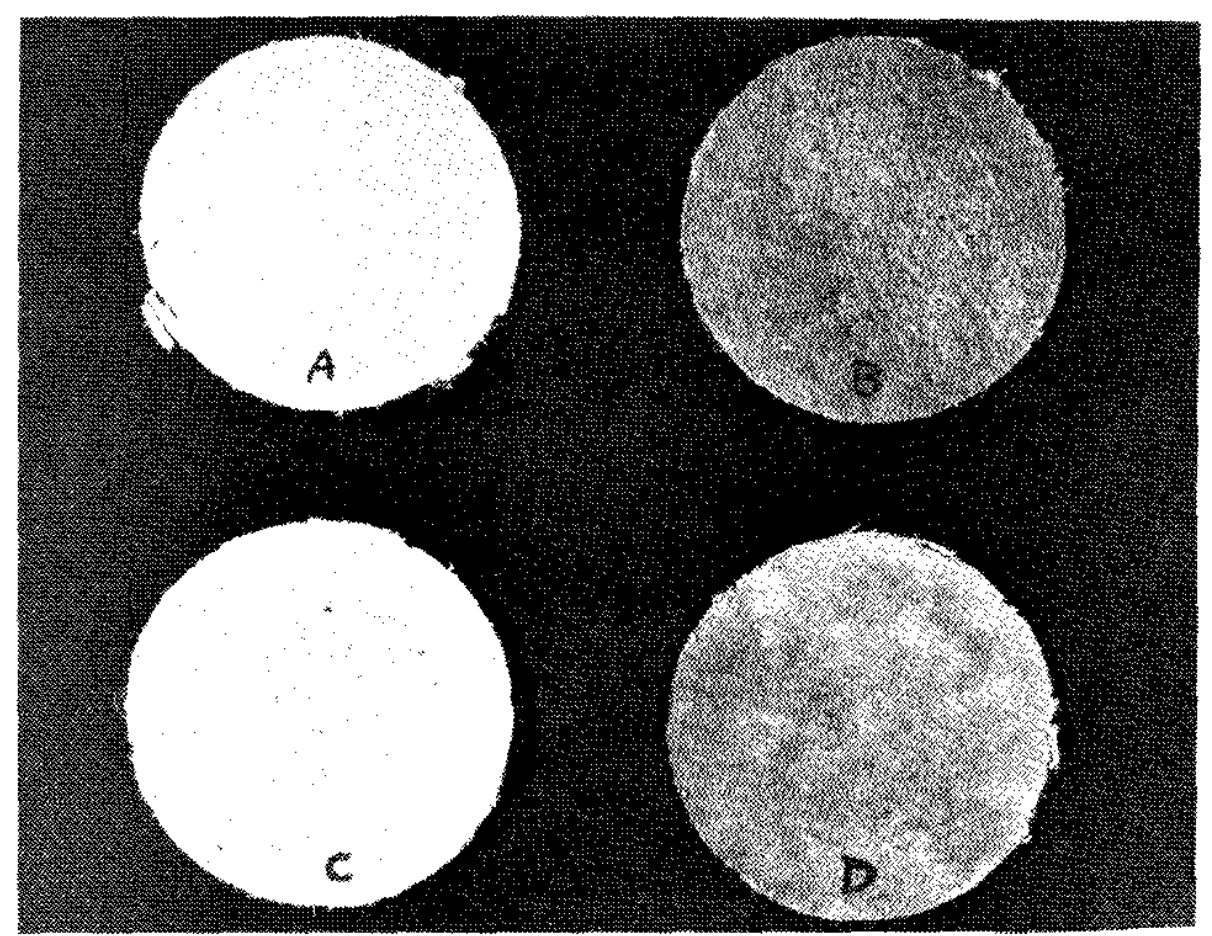

FIGURE 30. Separator Material

TABLE IX

Separator Irradiation Sumary

\begin{tabular}{|c|c|c|c|c|}
\hline Separator & & $A$ & & $B$ \\
\hline Exposed gamma doses rads & 0 & $5 \times 10^{7}$ & 0 & $5 \times 10$ \\
\hline Gas is weight, ib/3000 $t^{2}{ }^{2}$ & 385 & 182 & 225 & 220 \\
\hline Motsture content, wt wa & 3.0 & 2.6 & 3.6 & 2.2 \\
\hline $\begin{array}{l}\text { Weight loss after combustion } \\
\text { Wt \& }\end{array}$ & 36.5 & 17.0 & 16.1 & 16.3 \\
\hline Thickness, mils a & $11-13$ & $1\{-1\}$ & $16-18$ & $16-13$ \\
\hline 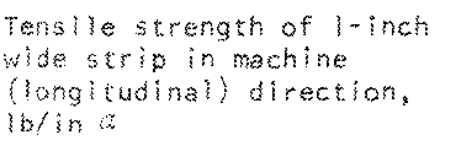 & 11 & 10 & 25 & 25 \\
\hline $\begin{array}{l}\text { Tensile strength of lminch } \\
\text { wide strip in cross } \\
\text { direction, lb/in }\end{array}$ & 30 & 28 & 37 & 36 \\
\hline color & Erown & Brown & Grey & grey \\
\hline
\end{tabular}

2 For definition of terms sed Reference 12 


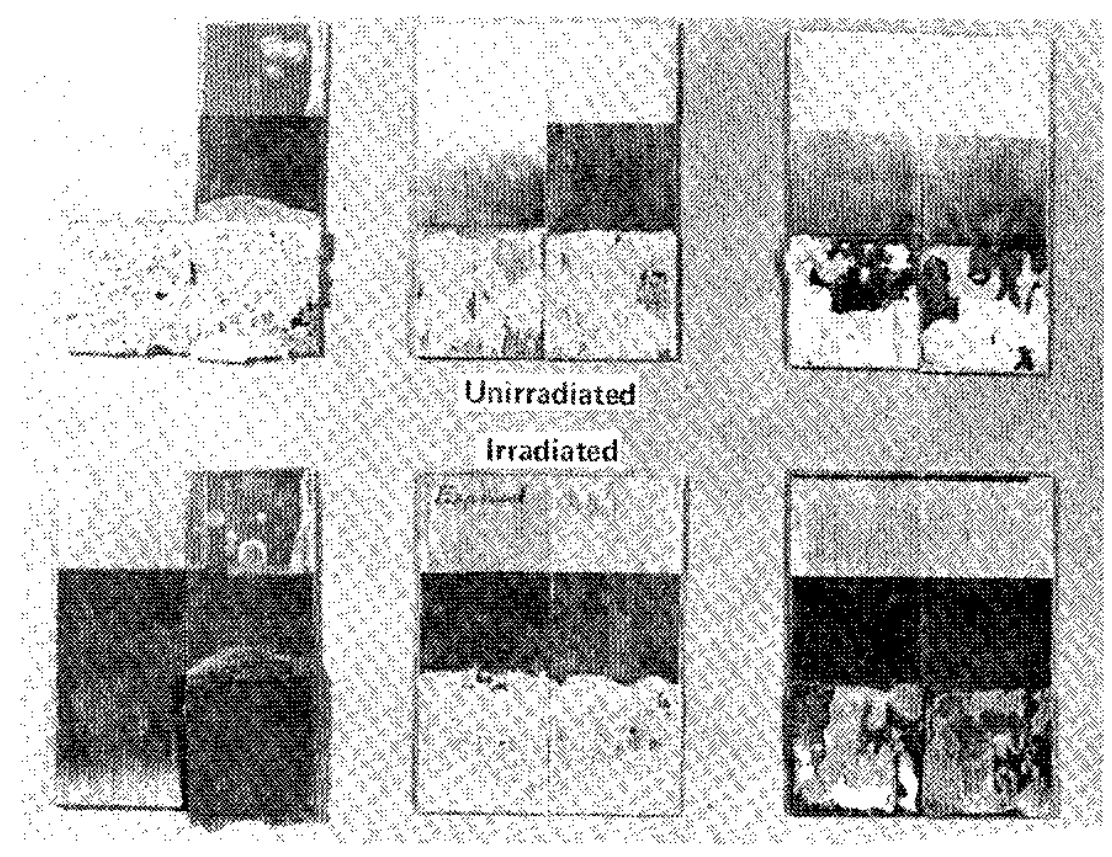

FIGURE 3\%. Adhesive Samples

TABLE X

Adhesive Irradiation Sumary

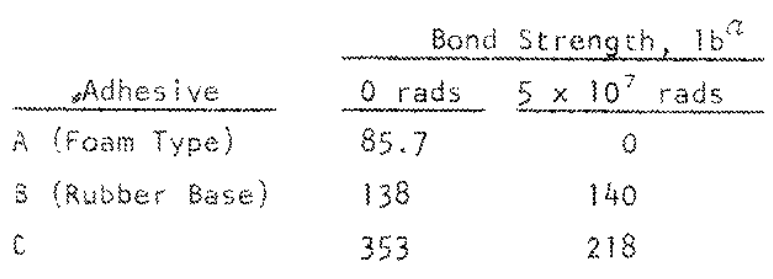

a. Shear strength of a 1-inchwide by Ininking bond. 


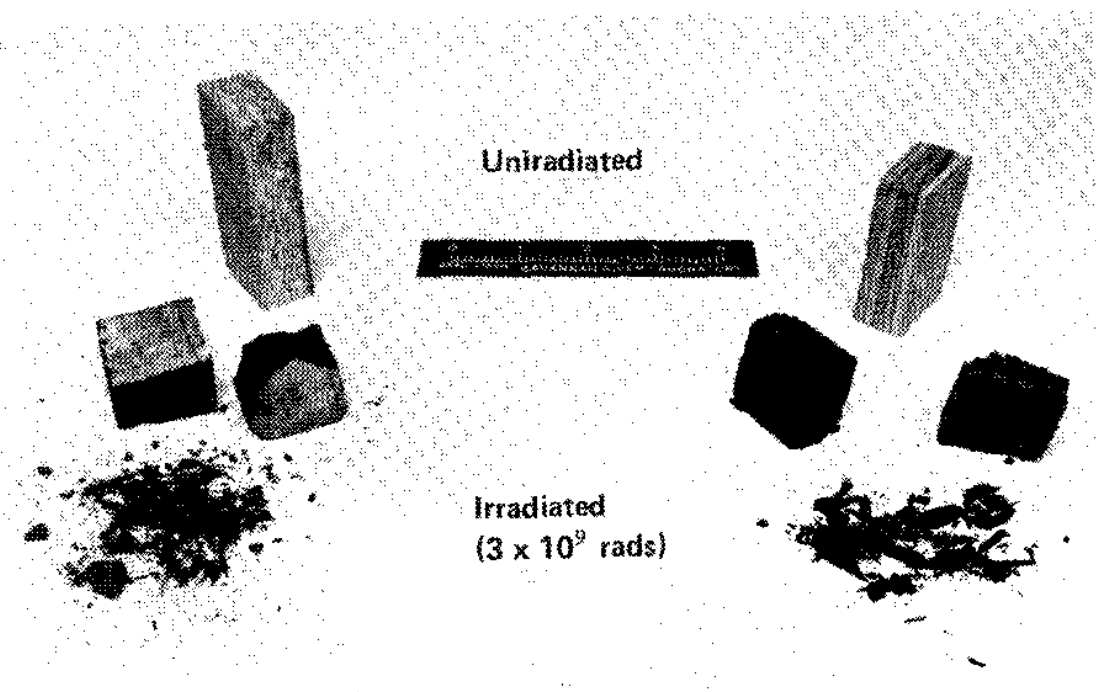

FIGURE 32. Framing Materials 


\section{ACKNOWLEDGMENTS}

The authors gratefully acknowledge the assistance of E. F. Sturcken of the Savannah River Laboratory for providing the scanning electron micrographs of carbon and HEPA filter media and the assistance of $W$. L. Anderson of the Naval Research Laboratory for providing samples and measurements for some of the confinement system component irradiation tests. 


\section{REFERENCES}

1. W. S. Durant, R. C. Milham, D. R. Muhlbaier, and A. H. Peters. Activity Confinement System of the Savannah River Plant Reactors. USAEC Report DP-1071, E. I. du Pont de Nemours \& Co., Savannah River Laboratory, Aiken, S. C. (1966).

2. W. S. Durant. Performance of Activated Carbon Beds in SRP Reactor Confinement Facilities - Progress Report:

September 1961-September 1965. USAEC Report DP-1028, E. I. du Pont de Nemours \& Co., Savannah River Laboratory, Aiken, S. C. (1966).

3. R. C. Milham. High Temperature Adsorbents for Iodine Progress Report: January 1965-September 1966. USAEC Report DP-1075, E. I. du Pont de Nemours \& Co., Savannah River Laboratory, Aiken, S. C. (1966).

4. R. C. Milham and L. R. Jones. Iodine and Noble Gas Retention Studies - Progress Report: October 1966-December 1968. USAEC Report DP-1209, E. I. du Pont de Nemours \& Co., Savannah River Laboratory, Aiken, S. C. (1969).

5. R. C. Milham and L. R. Jones. Iodine Retention Studies Progress Report: Jonuary 1969-June 1969. USAEC Report DP-1213, E. I. du Pont de Nemours \& Co., Savannah River Laboratory, Aiken, S. C. (1969).

6. R. C. Milham and L. R. Jones. Iodine Retention Studies Progress Report: July 1969-December 1969. USAEC Report DP-1234, E. I. du Pont de Nemours \& Co., Savannah River Laboratory, Aiken, S. C. (1970).

7. A. G. Evans and L. R. Jones. Iodine Retention Studies Progress Report: January 1970-June 1970. USAEC Report DP-1259, E. I. du Pont de Nemours \& Co., Savannah River Laboratory, Aiken, S. C. (1971).

8. A. G. Evans and L. R. Jones. Iodine Retention Studies Progress Report: July 1970-December 1970. USAEC Report DP-1271, E. I. du Pont de Nemours \& Co., Savannah River Laboratory, Aiken, S. C. (1971).

9. A. G. Evans and L. R. Jones. Confinement of Airborme Radioactivity - Progress Report: Jonuary 1971-June 1971. USAEC Report DP-1280, E. I. du Pont de Nemours \& Co., Savannah River Laboratory, Aiken, S. C. (1971). 
10. A. G. Evans and L. R. Jones. Confinement of Airborne Radioactivity - Progress Report: July 1971 - December 1971. USAEC Report DP-1298, E. I. du Pont de Nemours \& Co., Savannah River Laboratory, Aiken, S. C. (1971).

11 D. A. Collins, L. R. Taylor and R. Taylor. "The Development of Impregnated Charcoals for Trapping Methyl Iodide at High Humidity." Proceedings of Ninth $A E C$ Air Cleaning Conference. USAEC Report CONF-660904, Vol. 1, p 154-198 (1967).

12. W. L. Anderson. "Government and Industry Meeting on Filter Media and Media Testing." Proceedings of the Tenth AEC Air Cleaning Conference, USAEC Report CONF-680821, p 76-85 (1968).

13. J. W. Little, Jr. and J. W. Joseph, Jr. "Confinement of Airborne Activity from Melted Antimony Slugs." Proceedings of the Twelfth AEC Air Cleaning Conference, Oak Ridge, Tenn., August 28-31, 1972, to be published.

14. F. B. Longtin. Source Rod Failure and Subsequent Decontamination. USAEC Report DP-1305, E. I. du Pont de Nemours \& Co., Savannah River Laboratory, Aiken, S. C. (1972). 